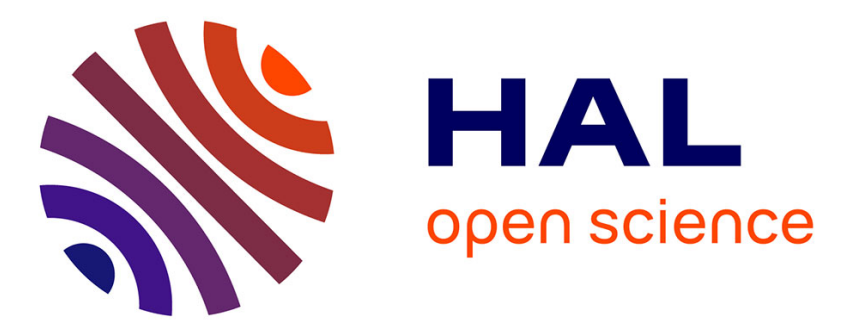

\title{
Atomic scale modeling of iron-doped biphasic calcium phosphate bioceramics
}

Sandrine Gomes, Amandeep Kaur, Jean-Marc Greneche, Jean-Marie Nedelec, Guillaume Renaudin

\section{- To cite this version:}

Sandrine Gomes, Amandeep Kaur, Jean-Marc Greneche, Jean-Marie Nedelec, Guillaume Renaudin. Atomic scale modeling of iron-doped biphasic calcium phosphate bioceramics. Acta Biomaterialia, 2017, 50, pp.78-88. 10.1016/j.actbio.2016.12.011 . hal-01476479

\section{HAL Id: hal-01476479 \\ https://hal.science/hal-01476479}

Submitted on 2 Mar 2017

HAL is a multi-disciplinary open access archive for the deposit and dissemination of scientific research documents, whether they are published or not. The documents may come from teaching and research institutions in France or abroad, or from public or private research centers.
L'archive ouverte pluridisciplinaire HAL, est destinée au dépôt et à la diffusion de documents scientifiques de niveau recherche, publiés ou non, émanant des établissements d'enseignement et de recherche français ou étrangers, des laboratoires publics ou privés.

\section{(c)(1)}

Distributed under a Creative Commons Attribution| 4.0 International License 


\title{
Atomic scale modeling of iron-doped biphasic calcium
}

\section{phosphate bioceramics}

Sandrine Gomes, ${ }^{1,2}$ Amandeep Kaur, ${ }^{1,2, \#}$ Jean-Marc Grenèche,${ }^{3}$ Jean-Marie Nedelec ${ }^{1,2}$ and Guillaume Renaudin ${ }^{1,2, *}$

${ }^{1}$ Université Clermont Auvergne, SIGMA Clermont, Institut de Chimie de Clermont-Ferrand, BP 10448, F-63000 Clermont-Ferrand, France.

${ }^{2}$ CNRS, UMR 6296, ICCF, F-63178 Aubière, France.

${ }^{3}$ Institut des Molécules et Matériaux du Mans, UMR CNRS 6283, Université du Maine, 72085 Le Mans Cedex, France

\begin{abstract}
:
Biphasic Calcium Phosphates (BCP) are bioceramics composed of hydroxyapatite (HAp, $\left.\mathrm{Ca}_{10}\left(\mathrm{PO}_{4}\right)_{6}(\mathrm{OH})_{2}\right)$ and beta-Tricalcium Phosphate $\left(\beta-\mathrm{TCP}, \mathrm{Ca}_{3}\left(\mathrm{PO}_{4}\right)_{2}\right)$. Because their chemical and mineral composition closely resembles that of the mineral component of bone, they are potentially interesting candidates for bone repair surgery, and doping can advantageously be used to improve their biological behavior. However, it is important to describe the doping mechanism of BCP thoroughly in order to be able to master its synthesis and then to fully appraise the benefit of the doping process. In the present paper we describe the ferric doping mechanism: the crystallographic description of our samples, sintered at between $500^{\circ} \mathrm{C}$ and $1100^{\circ} \mathrm{C}$, was provided by Rietveld analyses on X-ray powder diffraction, and the results were confirmed using X-ray absorption spectroscopy and ${ }^{57} \mathrm{Fe}$ Mössbauer spectrometry. The mechanism is temperature-dependent, like the previously reported zinc doping mechanism. Doping was performed on the HAp phase, at high temperature only, by an insertion mechanism. The $\mathrm{Fe}^{3+}$ interstitial site is located in the HAp hexagonal channel, shifted from its centre to form a triangular three-fold coordination. At lower temperatures, the $\mathrm{Fe}^{3+}$ are located at the centre of the channel, forming linear two-fold coordinated $\mathrm{O}-\mathrm{Fe}-\mathrm{O}$ entities. The knowledge of the doping mechanism is a prerequisite for a correct synthesis of the targeted bioceramic with the adapted $(\mathrm{Ca}=\mathrm{Fe}) / \mathrm{P}$ ratio, and so to be able to correctly predict its potential iron release or magnetic properties.
\end{abstract}

Keywords: Iron doping, Hydroxyapatite bioceramics, Rietveld refinement, X-ray Absorption Spectroscopy, Mössbauer spectrometry. 
Contact: Pr Guillaume Renaudin, guillaume.renaudin@ sigma-clermont.fr

\# present address: VIT University, Vellore, Tamil Nadu 632014, India.

\section{1- Introduction}

The mineral mass of bone is dominated by nanocrystalline non-stoichiometric hydroxyapatite (HAp, chemical formula $\mathrm{Ca}_{10}\left(\mathrm{PO}_{4}\right)_{6}(\mathrm{OH})_{2}, \mathrm{Ca} / \mathrm{P}$ ratio of 1.67) [1-4]. Non-stoichiometry is mainly assumed by few weight percent of carbonate substitution and also calcium deficiency, nevertheless many trace elements participate to the non-stoichiometry. Tricalcium phosphate ( $\beta$-TCP, chemical composition $\mathrm{Ca}_{3}\left(\mathrm{PO}_{4}\right)_{2}, \mathrm{Ca} / \mathrm{P}$ ratio of 1.5 ) has a $\mathrm{Ca} / \mathrm{P}$ ratio close to that of HAp and presents higher solubility under biological conditions [5-6]. HAp and BCP (biphasic calcium phosphates composed of a mixture of HAp and $\beta$-TCP) have been investigated for biomedical applications in reconstructive surgery (hard tissue replacement implants and bone prosthesis coating) due to their excellent bioactivities, biocompatibility and osteoconductivity [5-10]. In addition, the doping effect can advantageously be used, among other levers, to improve the biomedical properties of HAp-based ceramics [11]. Nanocrystalline bone mineral contains numerous essential trace elements $[4,9]$. The role of many of these ionic species in hard tissues is not fully understood, because of the difficulties encountered in monitoring and quantifying their proportions, which vary according to dietary alteration and to physiological and to pathological causes. However, it is commonly accepted that these various ions play a major role in the biochemistry of bones, enamel and dentine by a substitution process [12]. Our previous results on $\mathrm{Zn}$-doped $\mathrm{BCP}$ samples highlighted that a fine description of the incorporation mechanism of the doping element remains a significantfactorin correctly interpreting biological behavior, namely due to the different solubility of the two HAp and $\beta$ TCPphases [13-15]. The incorporation of the doping element in one or the other phases will deeply modify its potential release in biological fluid. The HAp structure is known to accept 
various ionic substitutions, as has been demonstrated for carbonate [16,17], silicate [18-21], borate $[22,23]$ and alkaline earth cations $\mathrm{Mg}^{2+}[24-26]$ and $\mathrm{Sr}^{2+}[27,28]$. Nevertheless our recent results on the Zn-doping mechanism demonstrated that substitution is not the only mechanism to be considered: insertion into an interstitial site [13], as also described for bevolite (the $\mathrm{Sr}$ equivalent with composition $\left.\mathrm{Sr}_{10}\left(\mathrm{PO}_{4}\right)_{6}(\mathrm{OH})_{2}\right)$ [29], has been established. This doping mechanism is temperature-dependent [14]. Zn-doping elements can be locatedin drastically different local environments. The transfer fromthe six-fold coordinated calcium site substitution in $\beta$-TCPat moderate temperature to the two-fold coordinated insertion in HAp at higher temperature is a significant phenomenon.

Following our Zn-doping insertion mechanism studies we undertook a systematic study of BCP doping by the 3d-metal cation series from manganese to zinc. The present paper is devoted to the specific case of ferric cations. Iron is an essential trace element in bones and teeth, is a micronutrient essential for various biological processes and is an important component of several metalloproteins. Iron represents approximately 35 and $45 \mathrm{mg} / \mathrm{kg}$ of body weight in adult women and men, respectively. In the intestinal lumen, iron exists in the form of ferrous and ferric salts, although most dietary inorganic iron is in the form of ferric salts [30]. Recent studies have shown that the presence of $\mathrm{Fe}^{3+}$ affects the crystallinity and solubility of HAp [31-34], while small amounts of iron were found to have a positiveimpact on the biomedical properties of HAp [35-37]. The blood compatibility, and more generally the biocompatibility and non-cytotoxicity, of $\mathrm{Fe}^{3+}$-doped HAp has recently been demonstrated, withimproved bactericidal and mineralizing properties compared to undoped HAp [38-40]. Biomagnetic calcium phosphate ceramics, incorporating magnetic ions and exhibiting ferromagnetic properties, play an important role in medicine. DopedmagneticHAp could be useful for biological applications such as magnetic resonance imaging (MRI), cell separation, drug delivery and heat mediation for the hyperthermia treatment of cancers $[39,41]$. 
Despite the recently-described insertion mechanism for $\mathrm{Zn}^{2+}[13-15]$ and despite the cationic size difference between $\mathrm{Fe}^{3+}(0.64 \AA, \mathrm{CN} 6)$ and $\mathrm{Ca}^{2+}(1.00 \AA, \mathrm{CN} 6)$ [42], a substitution mechanism at calcium crystallographic sites is commonly considered in the literatureas for all cations. In the present study, a detailed structural description of Fe-doped HAp is investigated to clarify the situation. Series of BCP samples (HAp being the main phase) are synthesized using the sol-gel method with different iron doping levels and with thermal treatments between $500^{\circ} \mathrm{C}$ and $1100^{\circ} \mathrm{C}$. In addition to a long-range order investigation performed using Rietveld refinement on X-ray powder diffraction patterns, the local order is finely described thanks to X-ray absorption spectroscopy and ${ }^{57} \mathrm{Fe}$ Mössbauer spectrometry.

\section{2- Materials and methods}

\subsection{Sol-gel elaboration of Fe-substituted BCP samples}

The sol-gel method previously proposed by the authors was used to synthesize one undoped and four Fe-doped series of BCP samples [14]. Briefly, to produce $2 \mathrm{~g}$ of undoped BCP powder, $4.7 \mathrm{~g}$ of $\mathrm{Ca}\left(\mathrm{NO}_{3}\right)_{2} .4 \mathrm{H}_{2} \mathrm{O}$ (Aldrich) and $0.84 \mathrm{~g}$ of $\mathrm{P}_{2} \mathrm{O}_{5}$ (Avocado Research chemicals) were dissolved in ethanol (anhydrous, $>99.5 \%$, Aldrich) under stirring and refluxed at $85^{\circ} \mathrm{C}$ for 24 hours. Thesolution was maintained at $55^{\circ} \mathrm{C}$ for 24 hours to obtain a as for all cations consistent gel, and then further heated to $80^{\circ} \mathrm{C}$ for 10 hours to obtain a white powder. Finally, the powder was sintered for 15 hours. Heat treatments were performed at $500^{\circ} \mathrm{C}, 600^{\circ} \mathrm{C}$, $700^{\circ} \mathrm{C}, 800^{\circ} \mathrm{C}, 900^{\circ} \mathrm{C}, 1000^{\circ} \mathrm{C}$ and $1100^{\circ} \mathrm{C}$ (series of seven samples with the same chemical composition). To prepare the Fe-doped samples, the required amount of $\mathrm{Fe}\left(\mathrm{NO}_{3}\right)_{3} \cdot 9 \mathrm{H}_{2} \mathrm{O}$ (Sigma-Aldrich) was added to the solution, simultaneously with $\mathrm{Ca}\left(\mathrm{NO}_{3}\right)_{2} \cdot 4 \mathrm{H}_{2} \mathrm{O}$ (SigmaAldrich). Nominal compositions were calculated assuming the insertion of $\mathrm{Fe}^{3+}$ cationsat the interstitial crystallographic site of hydroxyapatite; i.e. constant $\mathrm{Ca} / \mathrm{P}=1.67$. In the following, samples are labeled ' $x \mathrm{Fe}-T$ ' with $x=00,15,25,50$ and 75 for samples with respectively the 
targeted nominal $\quad \mathrm{Ca}_{10}\left(\mathrm{PO}_{4}\right)_{6}(\mathrm{OH})_{2}, \quad \mathrm{Ca}_{10} \mathrm{Fe}_{0.15}\left(\mathrm{PO}_{4}\right)_{6}(\mathrm{OH})_{1.55} \mathrm{O}_{0.45}$, $\mathrm{Ca}_{10} \mathrm{Fe}_{0.25}\left(\mathrm{PO}_{4}\right)_{6}(\mathrm{OH})_{1.25} \mathrm{O}_{0.75}, \quad \mathrm{Ca}_{10} \mathrm{Fe}_{0.50}\left(\mathrm{PO}_{4}\right)_{6}(\mathrm{OH})_{0.50} \mathrm{O}_{1.50} \quad$ and $\quad \mathrm{Ca}_{9.875} \mathrm{Fe}_{0.75}\left(\mathrm{PO}_{4}\right)_{6} \mathrm{O}_{2}$ compositions. Deprotonation of hydroxyl anions was first assumed to counterbalance the excess interstitial $\mathrm{Fe}^{3+}$ positive charges (i.e. three $\mathrm{H}^{+}$protons substitution by one $\mathrm{Fe}^{3+}$ ), followed by calcium deficiency for the higher iron amount in the $75 \mathrm{Fe}-T$ series. A total of 35 samples, distributed in five series according to chemical compositions, were synthesized and analyzed. Elemental analyses of the samples using ICP-AES confirmed that iron added in the solutions were well incorporated in the precipitates.

Sample color were sintering temperature-dependent. Powders obtained after the sol-gel process were white. Heat treatment at $500^{\circ} \mathrm{C}$ produced light grey samples, which became orange when the temperature increases and attained a rust color at $1000^{\circ} \mathrm{C}$ (the greater the iron content, the more pronounced the coloration is). Finally, heat treatment at $1100^{\circ} \mathrm{C}$ resulted in light purple powders.

\subsection{X-Ray Powder diffraction (XRPD) and Rietveld analyses}

XRPD patterns were recorded on a X'Pert Pro Philips diffractometer, with $\theta-\theta$ geometry, equipped with a solid X-Celerator detector and using $\mathrm{Cu} K \alpha$ radiation $(\lambda=1.54184 \AA)$. XRPD patterns were recorded at room temperature in the interval $3^{\circ}<2 \theta<120^{\circ}$, with a step size of $\Delta 2 \theta=0.0167^{\circ}$ and a counting time of $200 \mathrm{~s}$ for each data value. A total counting time of about 200 min was used for each sample (some raw data are showing in Figure SI1a from supplementary information). A XRPD pattern was collected from pure NIST standard $\mathrm{LaB}_{6} \mathrm{using}$ the same experimental conditions in order to extract the instrumental resolution function to improve peak profile fitting during Rietveld refinements.

Rietveld refinements of X-ray powder patterns were performed for each sample usingFullProf.2k software [43]. The procedure used (both data-collection and refinement 
strategy) corresponds to the general guidelines for structure refinement using the Rietveld (whole-profile) method formulated by the International Union of Crystallography Commission on Powder Diffraction [44-46]. The Rietveld refinement strategy was detailed in previous related work [14]. Examples of Rietveld plots are showing in Figure SI1b.

\section{$2.3 \underline{X \text {-ray Absorption Spectroscopy }(X A S)}$}

Fe K-edge Extended X-ray Absorption Fine Structure (EXAFS) spectra, simultaneously with the X-ray Absorption Near Edge Structure (XANES) part of the spectra, were acquired from the Fe-doped samples and two reference compounds $\left(\alpha-\mathrm{Fe}_{2} \mathrm{O}_{3}\right.$ and $\left.\mathrm{Fe}_{3} \mathrm{O}_{4}\right)$ using the SuperXAS beamline at Swiss Light Source (SLS, Villigen, Switzerland) in order to determine the electronic state as well as to accurately describe the coordination spheres of Fe atoms. The SLS synchrotron was running under standard ring conditions $(2.4 \mathrm{GeV}$ with an average current of $400 \mathrm{~mA})$. For energy collection, a Si(111) double-crystal monochromator - which offers an energy resolution of $\Delta \mathrm{E} / \mathrm{E}=2.0 \times 10^{-4}$ necessary to resolve the XANES structure was used. The experiments were calibrated using a metallic iron reference foil (K-edge 7709 $\mathrm{eV}$ ). Experiments were performed at room temperature and atmospheric pressure. Spectra were collected in an energy range between 7000 and $8000 \mathrm{eV}$, with the energy step varying from $0.5 \mathrm{eV}$ (XANES part) to $2.0 \mathrm{eV}$ (end of the EXAFS part) and 1s dwell time per point. XAS spectra were obtained in fluorescence mode using a 13-element Ge solid-state detector. The size of the beam was determined by a set of slits $(200 \mu \mathrm{m} \times 500 \mu \mathrm{m})$.

Data processing was performed using the Athena and Artemis programs from the IFFEFIT software package [47] by merging 6 successively-recorded absorption spectra. Single scattering theory was used here. Following Lengeler-Eisenberg normalization, EXAFS oscillations were Fourier Transformed (FT) using a Hanning window between 3.0 and $9.0 \AA^{-1}$. The $\chi(k)$ function was Fourier transformed using $k^{3}$ weighting, and all shell-by-shell fitting 
was done in $R$-space. Theoretical backscattering paths were calculated using successively ATOMS [48] and FEFF6 [49]. This data processing strategy was detailed in the Zn-doping study [15].

\section{$2.4^{57}$ Fe Mössbauer spectrometry}

The Fe-containing samples were analyzed by means of Mössbauer spectrometry using a conventional constant acceleration transmission device with a ${ }^{57} \mathrm{Co}(\mathrm{Rh})$ source. The samples, consisting of thin layers of powder with about $15 \mathrm{mg}$ of $\mathrm{Fe} / \mathrm{cm}^{2}$, were located on the transducer for $300 \mathrm{~K}$ and in a bath cryostat for $77 \mathrm{~K}$ measurements. The hyperfine parameters were refined by means of MOSFIT (unpublished program) by considering a suitable number of quadrupolar and/or magnetic components with lorentzian lines to describe the Mössbauer spectra. The isomer shift values quoted are those of $\alpha-\mathrm{Fe}$ at $300 \mathrm{~K}$ while the proportions of each species were estimated from the relative absorption area of their respective components, assuming the same recoilless Lamb-Mössbauer factor values.

\section{3- Results:}

\section{$\underline{3.1 \text { Rietveld analyses }}$}

\subsubsection{Mineralogical analysis of the samples}

To correctly interpret the behavior of our samples, their mineral compositions were estimated from the Rietveld refinements performed on Laboratory X-ray diffraction patterns. Mineral compositions for the five series of samples are indicated in Table 1, and the weight percent (wt \%) of the two main phases, HAp and $\beta$-TCP, are represented in Figure SI2 from supplementary information. In agreement with the targeted composition $\mathrm{Ca}_{10} \mathrm{Fe}_{x}\left(\mathrm{PO}_{4}\right)_{6}(\mathrm{OH})_{2}$ ${ }_{3 x} \mathrm{O}_{3 x}$, the samples which were heat treated at $500^{\circ} \mathrm{C}$ and $1100^{\circ} \mathrm{C}$ were mainly composed of the HAp phase, consistent with the interstitial mechanism for iron incorporation with constant 
$\mathrm{Ca} / \mathrm{P}$ ratio of 1.67 . The $\beta$-TCP phase was stabilized both by iron doping and by intermediate temperatures with the maximum amount observed at $700^{\circ} \mathrm{C}$. The maximum amount of $\beta$-TCP was observed at $800^{\circ} \mathrm{C}$ for the undoped series. Nevertheless, general changes in the HAp/ $\beta$ TCP weight ratio for undoped and Fe-doped series are similar. Except for the $25 \mathrm{Fe}-T$ series, all $x \mathrm{Fe}-T$ series show extremely similar temperature behaviors with single phase samples for heat treatments from $1000^{\circ} \mathrm{C}$. Combined with the two expected HAp and $\beta$-TCP phases, $\alpha$ CDP (with composition $\mathrm{Ca}_{2} \mathrm{P}_{2} \mathrm{O}_{7}$ ), $\mathrm{CaCO}_{3}, \mathrm{CaO}$ and $\alpha-\mathrm{Fe}_{2} \mathrm{O}_{3}$ (hematite) are temperature dependent impurities. For the Fe-doped series, $\mathrm{CaO}$ is never formed, $\mathrm{CaCO}_{3}$ is present up to $600^{\circ} \mathrm{C}, \alpha-\mathrm{CDP}$ is present up to $700^{\circ} \mathrm{C}$ and $\alpha-\mathrm{Fe}_{2} \mathrm{O}_{3}$ is series-dependent with a maximum amount observed at $1000^{\circ} \mathrm{C}$ (followed by a sharp decrease at $1100^{\circ} \mathrm{C}$ ). The destabilization of $\alpha-\mathrm{Fe}_{2} \mathrm{O}_{3}$ between $1000^{\circ} \mathrm{C}$ and $1100^{\circ} \mathrm{C}$ indicates that $\mathrm{Fe}$ atoms only really incorporate the HAp structure at $1100^{\circ} \mathrm{C}$.

\subsubsection{Lattice parameters of HAp and $\beta$-TCP}

The variations in the lattice parameters of HAp and $\beta$-TCP give initial indications about the mechanism of iron incorporation into their structures. Table SI1 presents refined lattice parameters for the HAp phase, while Figures1a and $1 \mathrm{~b}$ reports their variationswith respect to sintering temperature. Variations in the HAp lattice parameters can be decomposed into two steps: from $500^{\circ} \mathrm{C}$ to $1000^{\circ} \mathrm{C}$ only weak variations are observed (lattice parameters from the Fe-doped series are close to those of the undoped series) whereas drastic and anisotropic variations occur between $1000^{\circ} \mathrm{C}$ and $1100^{\circ} \mathrm{C}$. The sharp expansion of the $c$ lattice parameter combined with the contraction of the $a$ lattice parameter evince an interstitial mechanism of insertion of iron atoms into the HAp structure, as already described for the Zn-doping mechanism [14]. The increase in unit cell volume (Figure 1c) between $1000^{\circ} \mathrm{C}$ and $1100^{\circ} \mathrm{C}$ is not consistent with a substitution mechanism (as the $\mathrm{Fe}^{3+}$ cation is smaller than $\mathrm{Ca}^{2+}$ ). The 
drastic variations in the lattice parameters and unit cell volume are also directly dependent on the Fe quantity. We can note, for lower sintering temperatures, the slight decrease in the basal $a$ lattice parameter for the Fe-doped series, which could be attributed to a calcium substitution mechanism at $500^{\circ} \mathrm{C}$ and $600^{\circ} \mathrm{C}$.

The case of $\beta$-TCP is different. Table SI2 shows the refined lattice parameters of $\beta$-TCP as a function of the iron amount introduced for sintering temperatures which stabilize the $\beta$-TCP phase $\left(800^{\circ} \mathrm{C}\right.$ for the undoped series and $700^{\circ} \mathrm{C}$ for the iron-containing series). The values of both the $a$ and $c$ lattice parameters (and consequently that of unit cell volume) diminish with the increase in the iron doping level, in agreement with a calcium substitution mechanism. Substitution is first performedat the $\mathrm{Ca} 4$ site, and then is carried to the $\mathrm{Ca} 5$ site; i.e. calcium substitution from the low density column habitually encountered with this $\beta$-TCP phase [13$15,24,27,28]$.

\subsubsection{Location of $\mathrm{Fe}^{3+}$ in the HAp structure}

During Rietveld refinements the occupancy factors of all calcium and phosphorus crystallographic sites were systematically tested. Whatever the temperature and the Fe-doping level, no vacancies were evinced up to $1000^{\circ} \mathrm{C}$ (Table SI3), unlike iron-containing samples which had been heat treated at $1100^{\circ} \mathrm{C}$ (Table 2). For Fe-doped samples heat treated at $1100^{\circ} \mathrm{C}$, vacancies at the $\mathrm{Ca} 2$ site were refined for the $25 \mathrm{Fe}-T, 50 \mathrm{Fe}-T$ and $75 \mathrm{Fe}-T$ series leading to calcium-deficient hydroxyapatite. The vacancy amount increases with the Fedoping level, indicating that calcium vacancies participate in the charge compensation mechanism to counterbalance the positive charge brought by $\mathrm{Fe}^{3+}$ insertion.

Up to $1000^{\circ} \mathrm{C}$, Rietveld refinements, in agreement with mineralogical analysis and HAp lattice parameter variations, confirmed the insertion of $\mathrm{Fe}^{3+}$ cations at the interstitial $2 b$ Wyckoff site. Alimited quantity of iron cationswere located in the hexagonal channel at the 
$(0,0,0)$ position; corresponding to the refined $\mathrm{Ca}_{10} \mathrm{Fe}_{0.10(1)}\left(\mathrm{PO}_{4}\right)_{6}(\mathrm{OH})_{1.70} \mathrm{O}_{0.30}$ composition. Alimited amount of iron was still refined at this $2 b$ site for a sintering temperature of $1100^{\circ} \mathrm{C}$; nevertheless refined isotropic thermal factors for iron atoms located at the $2 b$ site became extremely large, and Fourier difference maps showed the presence of diffused electronic density around this $2 b$ site. A shift of the $\mathrm{Fe}$ atomic position from $(0,0,0)$ to the split $12 i$ $(x, 0,0)$ position improved the Rietveld agreement factors and enableda considerable increase in the refined iron occupancy amount (reaching the $\mathrm{Ca}_{9.77(1)} \mathrm{Fe}_{0.48(1)}\left(\mathrm{PO}_{4}\right)_{6}(\mathrm{OH})_{1.02} \mathrm{O}_{0.98}$ composition for $75 \mathrm{Fe}-1100$ samples:Table 2and Table SI1). The large increase in the refined quantity of incorporated iron correlates with the sharp variations in HAp lattice parameters between $1000^{\circ} \mathrm{C}$ and $1100^{\circ} \mathrm{C}$ (Figure 1 and Table SI1). Such splitting around the special $2 b$ site in apatite-type structures has already been described for Co-doped belovite $\mathrm{Co}: \mathrm{Sr}_{10}\left(\mathrm{PO}_{4}\right)_{6}(\mathrm{OH})_{2}$ [29]. Figure 1d shows the refined quantity of iron atoms inserted into the hexagonal channel of the apatite structure and Figure 2 illustrates variations in the $\mathrm{Fe}^{3+}$ local cation environment when going from the $2 b$ Wyckoff site to the shifted $(0.12,0,0)$ position. Variationsin Fe amount exactly follow the previously-described lattice parameters (or unit cell volume) variations. Iron is really incorporated into the HAp phase above $1000^{\circ} \mathrm{C}$. Refined compositions for $15 \mathrm{Fe}-1100$ and $25 \mathrm{Fe}-1100$ samples are close to the targeted composition: $\mathrm{Ca}_{10} \mathrm{Fe}_{0.18(1)}\left(\mathrm{PO}_{4}\right)_{6}(\mathrm{OH})_{1.46} \mathrm{O}_{0.54} \quad$ and $\mathrm{Ca}_{9.92(1)} \mathrm{Fe}_{0.26(1)}\left(\mathrm{PO}_{4}\right)_{6}(\mathrm{OH})_{1.38} \mathrm{O}_{0.62}$ for the targeted $\mathrm{Ca}_{10} \mathrm{Fe}_{0.15}\left(\mathrm{PO}_{4}\right)_{6}(\mathrm{OH})_{1.55} \mathrm{O}_{0.45}$ and $\mathrm{Ca}_{10} \mathrm{Fe}_{0.25}\left(\mathrm{PO}_{4}\right)_{6}(\mathrm{OH})_{1.25} \mathrm{O}_{0.75}$ compositions, respectively. Electroneutrality of the refined compositions was assumed by the deprotonation of hydroxyl anions, in combination with refined calcium vacancies when observed. For the other two samples, $50 \mathrm{Fe}-1100$ and $75 \mathrm{Fe}-$ 1100, the deviations from the targeted $\mathrm{Ca}_{10} \mathrm{Fe}_{0.50}\left(\mathrm{PO}_{4}\right)_{6}(\mathrm{OH})_{0.50} \mathrm{O}_{1.50}$ and $\mathrm{Ca}_{9.875} \mathrm{Fe}_{0.75}\left(\mathrm{PO}_{4}\right)_{6} \mathrm{O}_{2}$ are greater, $\mathrm{Ca}_{9.84(1)} \mathrm{Fe}_{0.37(1)}\left(\mathrm{PO}_{4}\right)_{6}(\mathrm{OH})_{1.21} \mathrm{O}_{0.79}$ and $\mathrm{Ca}_{9.77(1)} \mathrm{Fe}_{0.48(1)}\left(\mathrm{PO}_{4}\right)_{6}(\mathrm{OH})_{1.02} \mathrm{O}_{0.98}$, respectively. Here the maximum amount of iron incorporation into the HAp structure seems 
to form the $\mathrm{Ca}_{9.75} \mathrm{Fe}_{0.50}\left(\mathrm{PO}_{4}\right)_{6}(\mathrm{OH})_{1.00} \mathrm{O}_{1.00}$ compound: the shifted $2 b$ site is $25 \%$ occupied by $\mathrm{Fe}^{3+}$ cations. In this proposed chemical formula, the charge balance is assumed to be for two thirds by hydroxyl deprotonation and for one third by calcium vacancies at the $\mathrm{Ca} 2$ site.

The local environment of the iron cations is strongly affected by the splitting observed between $1000^{\circ} \mathrm{C}$ and $1100^{\circ} \mathrm{C}$. Up to $1000^{\circ} \mathrm{C}, \mathrm{Fe}^{3+}$ cations are located at the $2 b$ Wyckoff site, coordinates $(0,0,0)$, with a linear two-fold $\mathrm{O}-\mathrm{Fe}-\mathrm{O}$ coordination with two $\mathrm{Fe}-\mathrm{O} 4$ distances around $1.7 \AA$. Iron shift in the $12 i$ Wyckoff position observed at $1100^{\circ} \mathrm{C}$ lead to a new threefold coordination with three distances about $1.85 \AA$. Iron interatomic distances are reported in Table SI4 for both $1000^{\circ} \mathrm{C}$ and $1100^{\circ} \mathrm{C}$ sintering temperatures, and detail of the iron local environment are given in Comment SI1 from the supplementary information document.

\section{$\underline{3.2 X A S \text { analyses }}$}

Three samples of the $15 \mathrm{Fe}-T$ series $(15 \mathrm{Fe}-500,15 \mathrm{Fe}-800$ and $15 \mathrm{Fe}-1100$ samples), as well as two reference samples $\left(\alpha-\mathrm{Fe}_{2} \mathrm{O}_{3}\right.$ and $\left.\mathrm{Fe}_{3} \mathrm{O}_{4}\right)$, were investigated by XAS spectroscopy in fluorescence mode. The $15 \mathrm{Fe}-T$ series was chosen because of the single phase feature of the last 15Fe-1100 sample (Table1 and Figure SI2) and because of the absence of the $\alpha-\mathrm{Fe}_{2} \mathrm{O}_{3}$ phase for all the samples of the series. Reference materials were used to illustrate the wellknown tetrahedral and octahedral coordination for iron cations (considering $\mathrm{Fe}^{2+}$ and $\mathrm{Fe}^{3+}$ ).

\subsubsection{Temperature dependency of the spectra}

Raw data are reported in Figure SI3 showing the normalized EXAFS spectra, with the XANES part of the spectra and the EXAFS modulations for the $15 \mathrm{Fe}-T$ series and for the reference compounds. The temperature variation of the Fourier transformed amplitudes (not corrected for phase shift) is represented in Figure $3 \mathrm{a}$ in the $R$-space. The first peak in the 
radial distribution is observed at an $\mathrm{R}$ value of $1.4 \AA$ for samples $15 \mathrm{Fe}-500$ and $15 \mathrm{Fe}-800$ (same value for $\mathrm{Fe}_{3} \mathrm{O}_{4}$ with iron in tetrahedral and octahedral coordination, compared to 1.45 for $\alpha-\mathrm{Fe}_{2} \mathrm{O}_{3}$ with iron in octahedral coordination only). This first peak then shifts closer to $\mathrm{R}$ $=1.35 \AA$ for sample $15 \mathrm{Fe}-1100$, when a large amount of iron is inserted into the HAp network. In agreement with the XRPD long-range order analysis, local order considerations indicate a temperature-dependent iron incorporation mechanism in our BCP samples with low coordination at $1100^{\circ} \mathrm{C}$.

\subsection{2 $\mathrm{Fe}^{3+}$ insertion into HAp at $1100^{\circ} \mathrm{C}$}

EXAFS spectra from the single phase $15 \mathrm{Fe}-1100$ sample were used to explore the local $\mathrm{Fe}^{3+}$ environment determined by Rietveld refinement: insertion into a $12 i$ crystallographic site shifted from the $2 b$ site of the HAp structure (i.e. eccentric to the centre of the hexagonal column) leading to the three-fold coordination. The $k^{3}$-weighted fitted Fe K-edge EXAFS data of $15 \mathrm{Fe}-1100$ is illustrated in Figure $3 \mathrm{~b}$ (Fitting was performed using Artemis software in the range $1 \AA<R<3.8 \AA$, not corrected for phase shifts), and fit results are listed in Table 3 (phase shift corrected values).Due to the low symmetry of the iron position in the shifted $2 b$ site, 25 direct paths were considered in this $R$ range. The number of neighbors for each shell was fixed to their crystallographic values (to minimize the number of refined parameters) in the first step. During the final runs, the number of first nearest-neighbors was free in order to confirm the three-fold coordination of iron at $1100^{\circ} \mathrm{C}$. The results obtained unambiguously confirm the insertion of $\mathrm{Fe}^{3+}$ cations eccentrically from the $2 b$ Wyckoff site of the HAp structure with a three-fold coordination. The first amplitude observed for a short R distance agrees with a plane triangular $\mathrm{FeO}_{3}$ entity. The refined $\mathrm{Fe}-\mathrm{O}$ distances are 1.841 (2) $\AA$ for two Fe-O4 paths and 1.941 (7) $\AA$ for one Fe-O3 path. The refined number of closed oxygen neighbors was exactly 3.0, with 1.6(0.4) O4 + 1.4(0.3) O3. Local environment of iron is well 
described by EXAFS analysis, and the 'shift' column in Table 3 indicates that the long-range order crystallographic model used for Rietveld refinement is coherent.

\subsection{Results: ${ }^{57} \mathrm{Fe}$ Mössbauer spectrometry}

Spectra obtained at $300 \mathrm{~K}$ with quadrupolar hyperfine structure resulting from asymmetrical and non-lorentzian profile lines are illustrated in Figure 4. The fitting procedure (details are given in Comment SI2) allows us to propose a fitting model involving 2, 3 or 4 quadrupolar components (the fourth for the hematite impurity) with lorentzian lines without constraints on the linewidths (correlated to the site distribution: an increase in linewidth indicates a large local environment distribution). The refined values of hyperfine parameters are listed in Table 4. This model clearly enables $4 \mathrm{Fe}$ species to be distinguished, essentially from the isomer shift values, which can be related to the coordination number. Indeed, the larger the isomer shift value, the higher the coordination number.

The first quadrupolar component associated to an isomer shift value in the $0.15-0.17 \mathrm{~mm} / \mathrm{s}$ range is attributed to the two-fold coordinated Fe inserted into the center of the hexagonal channel of the HAp structure, while the second one, characterized by an isomer shift in the 0.21-0.23 range, is assigned to the three-fold coordinated Fe in the six-fold split position (as illustrated in Figure 2, left and right, respectively). Contrarily to frozen and definite crystallographic visualization of the samples indicating that the $1.1 \AA$ shift of the $\mathrm{Fe}^{3+}$ cation from the center of the hexagonal channel occurs from $1000^{\circ} \mathrm{C}$ only, ${ }^{57} \mathrm{Fe}$ Mössbauer local probe spectrometry brought a more realistic description of the samples, with a continuous variation on heating from the two-fold to the three-fold coordination for $\mathrm{Fe}^{3+}$ inserted into HAp: $100 \%$ two-fold for $15 \mathrm{Fe}-500\left(500^{\circ} \mathrm{C}\right.$ sintering temperature $), 40 \%$ two-fold versus 60 $\%$ three-fold for $15 \mathrm{Fe}-1000\left(1000^{\circ} \mathrm{C}\right.$ sintering temperature $)$ and $25 \%$ two-fold versus $75 \%$ three-fold for $15 \mathrm{Fe}-1100\left(1100^{\circ} \mathrm{C}\right.$ sintering temperature), as indicated in Table 4 . The 
evolution for series containing greater amounts of iron is described in Comment SI2. The quadrupolar splitting values for both the two-fold and the three-fold HApinserted $\mathrm{Fe}^{3+}$ remain quite similar: about $1.0 \mathrm{~mm} / \mathrm{s}$ for the two-fold $\mathrm{Fe}^{3+}$ and about 1.5 for the three-fold $\mathrm{Fe}^{3+}$ (sample 15Fe-500 only diverges slowly from these QS values). The third quadrupolar component (isomer shift $0.24-0.30 \mathrm{~mm} / \mathrm{s}$ ) is typical of Fe species located in a tetrahedral environment, while the last one and also the magnetic sextet (isomer shift $\sim 0.40 \mathrm{~mm} / \mathrm{s}$ ) corresponds to Fe located in an octahedral site. We can note the variation in the tetrahedral $\mathrm{Fe}^{3+}$ signal with heating: $\mathrm{IS}=0.24 \mathrm{~mm} / \mathrm{s}$ and $\mathrm{QS}=0.9 \mathrm{~mm} / \mathrm{s}$ for $15 \mathrm{Fe}-500$ sintered at $500^{\circ} \mathrm{C}$ against IS $=0.28-0.30 \mathrm{~mm} / \mathrm{s}$ and $\mathrm{QS}=2.1-2.3 \mathrm{~mm} / \mathrm{s}$ for samples sintered at $1000^{\circ} \mathrm{C}$ and $1100^{\circ} \mathrm{C}$.

The proportions of each Fe species (Table 4) are estimated from the relative absorption area, assuming the same Lamb-Mössbauer recoilless f-factorvalues: it is important to note that the proportions are also extremely dependent on the line width. It is also noteworthy that some of them are quite large, suggesting some distorted structures or, in the case of sample $75 \mathrm{Fe}-500$, the presence of superparamagnetic hematite nanoparticles, which transform into magnetic blocked hematite particles, the size of which is much larger, giving rise to a broadened quadrupolar doublet and a magnetic sextet, respectively. Consequently the results obtained from the $75 \mathrm{Fe}-500$ spectra are less precise; this can explain the absence of a tetrahedral signal and the overestimation of the three-fold component. Finally,all the observed components were attributed to ferric cations, in agreement with the XANES pre-edge position, indicating no oxidation state modification, whatever the sintering temperature. 


\section{4- Discussion}

\subsection{Temperature dependency of the BCP composition}

The present characterization of the $\mathrm{Fe}^{3+}$-doping mechanism of $\mathrm{BCP}$ bioceramics is highly similar to that previously described in detail for $\mathrm{Zn}^{2+}$ [13-15]. With lower sintering temperatures, BCP samples are mainly composed of the undoped HAp phase. Figure SI4 shows temperature dependency of the total refined iron content in the samples for the four Fecontaining series when considering Fe inserted into the two main calcium phosphates (HAp and $\beta$-TCP) and iron from hematite. The lack of metal transition for lower temperatures was already observed in our previous Zn-BCP doping study [14]. EXAFS characterization of the Zn-BCP samples showed that the amount of metal transition, undetectable up to $800^{\circ} \mathrm{C}$ by XRPD long-rang order characterization, is certainly due to cation physisorption on the HAp surface. Present EXAFS results on iron doping indicate that $\mathrm{Fe}^{3+}$ cations undetectable by longrange order technic are in tetrahedral coordination. In comparison with Fourier transformed amplitudes of $\mathrm{Fe}_{3} \mathrm{O}_{4}$ (first peak at $\mathrm{R}=1.4 \AA$ ), we can assume that part of the iron is in tetrahedral coordination for heat treatments performed at $500^{\circ} \mathrm{C}$ and $800^{\circ} \mathrm{C}$ (Figure 3a). Variation of the assigned tetrahedral signal from Mössbauer spectroscopy (Table 4 with the two tetra phys. and tetra amorph. assignments) highlighted the evolution of the location ofthese fourfold coordinated $\mathrm{Fe}^{3+}$ cations from a physisorbed state at the HAp surface for the lower sintering temperature toa gradually incorporated state (by diffusion) into the Fe-doped HAp amorphous, or poorly crystallized,shell. These observations corroborate already published results. HAp surface tetrahedral ferric cations have been observed using iron Mössbauer spectroscopy by previous researchers [50,51] with the same distinguishable assignments for physisorbed surface $\mathrm{Fe}^{3+}$ cations and $\mathrm{Fe}^{3+}$ cations located in an amorphous part of the sample (respectively with IS $=0.28$ and 0.30 by Jiang et al. [51]; versus respectively IS $=0.24$ and $0.28-0.30$ in the present work). 
For intermediate sintering temperatures, the Fe-doped $\beta$-TCP phase is stabilized $(\sim 20 \mathrm{wt} \%$ of $\mathrm{BCP}$ ) in presence of the undoped (or weakly doped) HAp main phase. And for higher sintering temperatures (above $1000^{\circ} \mathrm{C}$ ), BCP samples are quite exclusively composed of $\mathrm{Fe}$ doped HAp. At $700^{\circ} \mathrm{C}-800^{\circ} \mathrm{C}$, iron substitution in the stabilized Fe: $\beta$-TCP phase is demonstrated by an increase in the total amount of refined iron (Figure SI4), and by the Rietveld refinement of the $\beta$-TCP structure (Table SI2) with a maximum doping level $\mathrm{Ca}_{2.6} \mathrm{Fe}_{0.4}\left(\mathrm{PO}_{4}\right)_{2}$.

The iron incorporated targeted values are reached at $1100^{\circ}$ for the $15 \mathrm{Fe}-1100$ and $25 \mathrm{Fe}-1100$ samples (Figure SI4). For the other two series, the samples at $1100^{\circ} \mathrm{C}$ still exhibit a deficit in total refined iron content, indicating that either the Fe occupancies in the shifted $2 b$ site are underestimated during Rietveld refinement (due to the great disorder around this $2 b$ position) or a small amount of nanosized iron-containing oxide is present. On the other hand the temperature dependency of the EXAFS spectra, in agreement with the crystallographic description, illustrates that the main change in the iron local environment is realized at $1100^{\circ} \mathrm{C} .15 \mathrm{Fe}-500,15 \mathrm{Fe}-800$ and $15 \mathrm{Fe}-1100$ spectra reveal the same pre-edge signal at 7114 $\mathrm{eV}$, characteristic of ferric cations [52], and EXAFS modulations show more definite contributions in the $15 \mathrm{Fe}-1100$ spectra with a shoulder before the Fe K-edge close to $7120 \mathrm{eV}$ (not present in the other samples of the series or in the reference materials). Figure 3 reveals low iron coordination with short interatomic $\mathrm{Fe}-\mathrm{O}$ distances at $1100^{\circ} \mathrm{C}$ at about $1.9 \AA$ (Table 3).

\subsection{Iron location into the HAp structure}

The iron doping mechanism is dependent on sintering temperature, with an interstitial mechanism for iron insertion into the HAp structure that is realized for the higher temperature. An important specific characteristic of this iron-doping mechanism, compared to 
the previously reported zinc doping studies [13-15], is the splitting of the ferric cation out of the centre of the hexagonal channel. It clearly appears that iron insertion in the shifted $2 b$ site at $1100^{\circ} \mathrm{C}$ (Table 2), correlated to the sharp variation of the HAp lattice parameters (Figure 1), enabled a considerable increase of the iron quantity in the hexagonal HAp channel (from about 0.5 wt $\%$ up to $1000^{\circ} \mathrm{C}$ to a value higher than $2.5 \mathrm{wt} \%$ at $1100^{\circ} \mathrm{C}$ ).

The low IS signals,from Mössbauer spectroscopy, we have attributed to $\mathrm{Fe}^{3+}$ inserted into the HAp structure - corresponding to the linear HAp and triang. HAp assignments in Table 4 have never been observed previously. This should be correlated with the synthesis process; samples were simply heated at $100^{\circ} \mathrm{C}$ in the study of Jiang et al. [50], and calcinations were performed under nitrogen in the study of Low et al. [51]. It is surprising to observe so great a difference between our samples sintered under air, showing one or two components with IS < 0.2, which was not the case when heating under nitrogen, where the smallest IS valuewas 0.27 [50]. XAS and Mössbauer spectroscopycorroborates the refutation ofa modification of the oxidation state of ferric cations during the sintering process; the whole population of iron cations is trivalent $\mathrm{Fe}^{3+}$ whatever our doped samples. Previously reported studies on irondoped hydroxyapatites highlight the importance of the synthesis approach. Chandra et al. [38] prepared Fe-doped HAp using a combination of hydrothermal and microwave techniques, and observed a decrease in both the $a$ and chexagonal lattice parameters of HAp with an increase in Fe doping. This does not correspond with our results (anisotropic variation, particularly at a high sintering temperature), and seems to reflect a calcium substitution mechanism. It should be noted that for thelower sintering temperature we also observe a decrease in the basal $a$ lattice parameter combined with an absence of variation in the hexagonal $c$ lattice parameter (Table SI1 and Figure 1). Thus a weak calcium substitution cannot be excluded, even if the Rietveld refinements did not enable us to detect it. The X-ray electronic contrast between $\mathrm{Fe}^{3+}$ and $\mathrm{Ca}^{2+}$ is not very marked, and a possible combination of iron to calcium substitution with a 
calcium site deficiency (as reported for the 75Fe-series in Table 2) could mask such a calcium substitution mechanism for the lower sintering temperatures. This hypothesis should be excluded for higher sintering temperatures, as indicated by $1 /$ lattice parameter variation, $2 /$ presence of electronic density at the interstitial site and 3/ the low coordination revealed by XAS and Mössbauer spectroscopy for iron. In the same way, the freeze-drying process used by Tampieri et al. [39] led to the preparation of Fe-doped HAP samples without the inserted iron atoms, as illustrated by their EXAFS study. They obtained a first contribution in the uncorrected radial distribution at about $1.5 \AA$, which was similar to the measured magnetite and maghemite reference materials. The corresponding Fe-O distance is typical of a ferric cation (about $1.95 \AA$ ), larger than our refined $1.84 \AA$ value (Table 3) obtained with a first contribution in the uncorrected radial distribution at about $1.35 \AA$ (Figure $3 \mathrm{~b}$ ).

The shift from the $2 b$ Wyckoff site to the $12 i$ Wyckoff site $(x \sim 0.12)$ allows three-fold coordination for the $\mathrm{Fe}^{3+}$ cation (compared to the permanent linear two-fold coordination for $\left.\mathrm{Zn}^{2+}\right)$ and enables an increase in the inserted doping quantity in $\mathrm{Ca}_{10} M_{x}\left(\mathrm{PO}_{4}\right)_{6}(\mathrm{OH})_{2-\mathrm{y}} \mathrm{O}_{y}$, with $x_{\text {max }} \sim 0.25$ for $\mathrm{Zn}^{2+}$ versus 0.50 for $\mathrm{Fe}^{3+}$. This crystallographic feature has already been described for apatite-type materials. The insertion of $\mathrm{Co}^{2+}$ into the belovite phase (the strontium analogue of hydroxyapatite $\left.\mathrm{Sr}_{10}\left(\mathrm{PO}_{4}\right)_{6}(\mathrm{OH})_{2}\right)$ has been studied by Kazin et al. [29] on single crystals prepared at $1300^{\circ} \mathrm{C}$. X-ray single crystal diffraction unambiguously indicates that $\mathrm{Co}^{2+}$ cations are located along the hexagonal channel by an insertion mechanism, and are shifted from its centre. The same $12 i$ Wyckoff site was used by the authors to describe Co-doped belovite. The only difference with our Fe-doped HAp description is in the shift amplitude: $0.6 \AA$ for $\mathrm{Sr}_{10} \mathrm{Co}_{0.4}\left(\mathrm{PO}_{4}\right)_{6}(\mathrm{OH})_{0.8} \mathrm{O}$ against $1.1 \AA$ in our $\mathrm{Ca}_{9.75} \mathrm{Fe}_{0.50}\left(\mathrm{PO}_{4}\right)_{6}(\mathrm{OH}) \mathrm{O}$ compound. Our greater eccentric shift has the advantage of clearly indicating the passage from the two-fold to the three-fold coordination for the shifted inserted cation (Figure 2 and Table 3). 


\section{5- Conclusion}

The temperature-dependent $\mathrm{BCP}$ iron doping mechanism is very close to the previously described zinc doping case. Three different BCP compositions were observed,depending on the sintering temperature: $1 /$ for temperatures below $600^{\circ} \mathrm{C}$, the undoped $\mathrm{HAp}$ is nearly the only crystalline phase in $\mathrm{BCP}$, and iron doping cations are physisorbed at its surface; 2 / for intermediate temperatures, BCP samples are composed of about 80 wt $\%$ of undoped HAp and about 20 wt $\%$ of iron-doped $\beta$-TCP with ferric cations located at the poorly crystallized shells; and $3 /$ for temperatures higher than $1000^{\circ} \mathrm{C}, \mathrm{BCP}$ are quite exclusively composed of iron-doped HAp,again with some of the ferric cations located at a poorly crystallized surface. Ferric incorporation into the $\beta$-TCP structure to form Fe-doped $\beta$-TCP with composition $\mathrm{Ca}_{2.6} \mathrm{Fe}_{0.4}\left(\mathrm{PO}_{4}\right)_{2}$ is performed using a calcium substitution mechanism at the $\mathrm{Ca} 4$ and $\mathrm{Ca} 5$ crystallographic sites (i.e. the low density column of the $\beta$-TCP structure). On the other hand, ferric incorporation into the HAp structure to form Fe-doped HAp with composition $\mathrm{Ca}_{9.75} \mathrm{Fe}_{0.50}\left(\mathrm{PO}_{4}\right)_{6}(\mathrm{OH}) \mathrm{O}$ is performed using an insertion mechanism with $\mathrm{Fe}^{3+}$ cations located in the HAp hexagonal channel. The main difference with the $\mathrm{Zn}^{2+}$ case is the thermal evolutionof this interstitial location. Whereas the $\mathrm{Zn}^{2+}$ cation is permanently located in the centre of the hexagonal channel at the $2 b$ crystallographic site $\left(P 6_{3} / m\right.$ space group) at whatever sintering temperature between $500^{\circ} \mathrm{C}$ and $1100^{\circ} \mathrm{C}, \mathrm{Fe}^{3+}$ cations move away from the channel center to the eccentric six-fold split $12 i$ crystallographic site for sintering temperatures above $1000^{\circ} \mathrm{C}$. This shifted position enables the passage from a two-fold to a three-fold coordination for $\mathrm{Fe}^{3+}$. To the best of the authors' knowledge, these two low coordination numbers for iron (linear and triangular) have been observed and described for the first time in this paper. All the long-range order crystallographic descriptions of $\mathrm{Fe}^{3+}-$ doped HAp obtained from Rietveld analyses of XRPD have been strengthened by XAS 
(XANES and EXAFS) and ${ }^{57} \mathrm{Fe}$ Mössbauer spectroscopies. These techniques show that the passage from the two-fold to the three-fold coordination of $\mathrm{Fe}^{3+}$ in the hexagonal channel does not occur spontaneously at $1000^{\circ} \mathrm{C}$ (as long-range order investigation seemed to indicate) but is gradually achieved and enhanced with temperature.

These results on the iron doping of BCP samples should be considered, taken into account the applied sintering temperature, when preparing such bioceramics with the controlled $(\mathrm{Ca}+\mathrm{Fe}) / \mathrm{P}$ ratio by keeping constant the $\mathrm{Ca} / \mathrm{P}$ ratio at 1.67 . Indeed it strongly impacts the final mineral composition of the synthesized samples. And, ultimately, it will impact the iron potential release in the body (as $\beta$-TCP and HAp have strongly different solubilities)or their eventual magnetic properties.

\section{Acknowledgements}

This work was supported by ANR under project NANOSHAP (ANR-09-BLAN-0120-03). We acknowledge SLS for provision of synchrotron radiation facilities and we would like to thank Maarten Nachtegaal for assistance in using beamline SuperXas.

\section{References}

[1] S.G. Dahl, P. Allain, P.J. Marie, Y. Mauras, G. Boivin, P. Ammann, Y. Tsouderos, P.D. Delmas, C. Christiansen, Incorporation and distribution of strontium in bone, Bone, 28 (2001) 446-453.

[2] R. Lagier, C.A. Baud, Magnesium whitlockite, a calcium phosphate crystal of special interest in pathology, Pathol. Res. Pract. 199 (2003) 329-335.

[3] R.S. Lee, M.V. Kayser, S.Y. Ali, Calcium phosphate microcrystal deposition in the human intervertebral disc, J. Anat. 208 (2006) 13-19. 
[4] C. Rey, C. Combes, C. Drouet, M.J. Glimcher, Bone mineral: update on chemical composition and structure, Osteoporosis Int. 20 (2009) 1013-1021.

[5] S.V. Dorozhkin, Calcium orthophosphates: applications in nature, biology, and medicine, Pan Stanford, Singapore, 2012, 854 pp.

[6] J.C. Elliot, in Structure and chemistry of the apatites and other calcium orthophosphates, Amsterdam: Elsevier; 1994.

[7] W. Suchanek, M. Yoshimura, Processing and properties of hydroxyapatite-based biomaterials for use as hard tissue replacement implants, J. Mater. Res. 13 (1998) 94-117.

[8] S.V. Dorozhkin, Biphasic, triphasic and multiphasic calcium orthophosphates, Acta Biomaterialia, 8 (2012) 963-977.

[9] S.V. Dorozhkin, Medical Application of Calcium Orthophosphate Bioceramics, BIO, 1 (2011) 1-51.

[10] S.M. Zakaria, S.H.S. Zein, M.R. Othman, F. Yang, J.A. Jansen, Nanophase hydroxyapatite as a biomaterial in advanced hard tissue engineering: a review, Tissue Eng. B: Reviews 19 (2013) 431-441.

[11] M. Bohner, L. Galea, N. Doebelin, Calcium phosphate bone graft substitutes: Failures and hopes, Journal of the European Ceramic Society, 32 (2012) 2663-2671

[12] A. Bigi, G. Cojazzi, S. Panzavolta, A. Ripamonti, N. Roveri, M. Romanello, K. Noris Suarez, L. Moro, Chemical and structural characterization of the mineral phase from cortical and trabecular bone, J. Inorg. Biochem. 68 (1997) 45-51.

[13] S. Gomes, J.-M. Nedelec, E. Jallot, D. Sheptyakov, G. Renaudin, Unexpected mechanism of $\mathrm{Zn}^{2+}$ insertion in calcium phosphate bioceramics, Chem. Mat. 23 (2011) 3072-3085.

[14] S. Gomes, J.-M. Nedelec, G. Renaudin, On the effect of temperature on the insertion of zinc into hydroxyapatite,Acta Biomaterialia 2012 (8) 1180-1189. 
[15] S. Gomes, A. Kaur, J.-M. Nedelec, G. Renaudin, X-ray absorption spectroscopy shining (synchrotron) light onto the insertion of $\mathrm{Zn}^{2+}$ in calcium phosphate ceramics and its influence on their behaviour under biological conditions, J. Mater. Chem. B, 2014, 2, 536-545.

[16] F. Babonneau, C. Bonhomme, S. Hayakawa and A. Osaka (2006). Solid State NMR Characterization of Nano-crystalline hydroxy-carbonate Apatite Using 1H-31P-13C Triple Resonance Experiments. MRS Proceedings, 984, 0984-MM06-05 doi:10.1557/PROC-9840984-MM06-05.

[17] K.A. Hing, J.C. Merry, I.R. Gibson, L. Di-Silvio, S.M. Best, W. Bonfield, Effect of carbonate content on the response of human osteoblast like cells to carbonate substituted hydroxyapatite, Bioceramics, 12 (1999) 195-198.

[18] M. Palard, E. Champion, S. Foucaud, Synthesis of silicate hydroxyapatite $\mathrm{Ca}_{10}\left(\mathrm{PO}_{4}\right)_{6-\mathrm{x}}\left(\mathrm{SiO}_{4}\right)_{\mathrm{x}}(\mathrm{OH})_{2-\mathrm{x}}$, J Solid State Chem, 181 (2008) 1950-1960.

[19] S. Gomes, G. Renaudin, A. Mesbah, E. Jallot, C. Bonhomme, F. Babonneau, J.-M. Nedelec, Thorough analysis of silicon substitution in biphasic calcium phosphate bioceramics: a multi-technique study, Acta Biomater, 6 (2010) 3264-3274.

[20] G. Gasqueres, C. Bonhomme, J. Maquet, F. Babonneau, S. Hayakawa, T. Kanaya and A. Osaka, Revisiting silicate substituted hydroxyapatite by solid state NMR, Magn Reson Chem, 46 (2008) 342-346.

[21] S. Gomes, J.-M. Nedelec, E. Jallot, D. Sheptyakov and G. Renaudin, Silicon location in silicate-substituted calcium phosphate ceramics determined by neutron diffraction, Crystal Growth and Design, 11 (2011) 4017-4026.

[22] S. Hayakawa, A. Sakai, K. Tsuru, A. Osaka, E. Fujii, K. Kawabata, C. Jaeger, Preparation and characterization of boron-containing hydroxyapatite, Key Eng Mater, 361363 (2008)191-194. 
[23] S. Barheine, S. Hayakawa, C. Jäger, Y. Shorosaki, A. Osaka, Effect of disordered structure of boron-containing calcium phosphates on their in vitro biodegradability, $\mathrm{J}$ Am Ceram Soc, 94 (2011) 2656-2662.

[24] S. Gomes, G. Renaudin, E. Jallot and J.-M. Nedelec, Structural characterization and biological fluid interaction of sol-gel derived $\mathrm{Mg}$-substituted biphasic calcium phosphate ceramics, Applied Materials and Interfaces, 01 (2009) 505-513.

[25] SarahDiallo-Garcia, DanielleLaurencin, Jean-MarcKrafft, SandraCasale, Mark E.Smith, HélèneLauron-Pernot, and GuylèneCostentin, Influence of Magnesium Substitution on the Basic Properties of Hydroxyapatites, The Journal of Physical Chemistry C, 115 (2011) 24317 24327.

[26] D.Laurencin, C.Gervais, H.Stork, S.Krämer, D.Massiot, and F.Fayon , ${ }^{25} \mathrm{Mg}$ Solid-State NMR of Magnesium Phosphates: High Magnetic Field Experiments and Density Functional Theory Calculations, The Journal of Physical Chemistry C, 116 (2012) 19984-19995.

[27] G. Renaudin, P. Laquerrière, Y. Filinchuk, E. Jallot and J.-M. Nedelec, Structural characterization of sol-gel derived Sr-substituted calcium phosphates with anti-osteoporotic and anti-inflammatory properties, Journal of Materials Chemistry, 18 (2008) 3593-3600.

[28] G. Renaudin, E. Jallot and J.-M. Nedelec, Effect of strontium substitution on the composition and microstructure of sol-gel derived calcium phosphate, Journal of Sol Gel Science and Technology, 51 (2009) 287-294.

[29] P.E. Kazin, O.R. Gazizova, A.S. Karpov, M. Jansen, Y.D. Tretyakov, Incorporation of 3d-metal ions in the hexagonal channels of the $\mathrm{Sr}_{5}\left(\mathrm{PO}_{4}\right)_{3} \mathrm{OH}$ apatite, Solid State Sciences, $9(2007) 82-87$.

[30] P.T. Lieu, M. Heiskala, P.A. Peterson, Y. Yang, The roles of iron in health and disease, Mol. Aspects Med., 22 (2001) 1-87. 
[31] W. Pon-On, N. Charoenphandhu, J. Teeraporpuntakit, J. Thongbunchoo, N. Krishnamra, I.M. Tang, Physicochemical and biochemical properties of iron-loaded silicon substituted hydroxyapatite (FeSiHAp), Mater. Chem. Phys., 141 (2013) 850-860.

[32] Q. Chang, D.L. Chen, H.Q. Ru, X.Y. Yue, L. Yu, C.P. Zhang, Toughening mechanism in iron-containing hydroxyapatite/titanium composite, Biomaterials, 31 (2010) 1493-1501.

[33] W. Pon-On, S. Meejoo, I.M. Tang, Substitution of manganese and iron into hydroxyapatite: core/shell nanoparticles, Mater. Res. Bull., 43 (2008) 2137-2144.

[34] O. Kaygili, S.V. Dorozhkin, T. Ates, A.A. Al-Ghamdi, F. Yakuphanoglu, Dielectric properties of Fe doped hydroxyapatite prepared by sol gel method, Ceramics International, 40 (2016) 9395-9402.

[35] S. Panseri, C. Cunha, T. D’Alessandro, M. Sandri, G. Giavaresi, M. Marcacci, C.T. Hung, A. Tampieri, Intrinsically superparamagnetic Fe-hydroxyapatite nanoparticles positively influence osteoblast-like behaviour, J. Nanobiotechnology, 10 (2012) 32.

[36] Y. Li, J. Widodo, S. Lim, C.P. Ooi, Synthesis and cytocompatibility of manganese (II) and iron (III) substituted hydroxyapatite nanoparticles, J. Mater. Sci., 47 (2012) 754-763.

[37] M. Iafisco, M. Sandri, S. Panseri, J.M. Delgado-Lopez, J. Gomez-Morales, A. Tampieri, Magnetic bioactive and biodegradable hollow Fe-doped hydroxyapatite coated poly(L-lactic) acid micro-nanospheres, Chem. Mater., 25 (2013) 2610-2617.

[38] V. S. Chandra, G. Baskar, R.V. Suganthi, K. Elayaraja, M.I.A. Joshy, W.S. Beaula, R. Mythili, G. Venkatraman, S.N. Kalkura, Blood compatibility of iron-doped nanosize hydroxyapatite and its drug release, Appl. Mat. Interfaces, 4 (2012) 1200-1210.

[39] A. Tampieri, T.a D’Alessandro, M. Sandri, S. Sprio, E. Landi, L. Bertinetti, S. Panseri, G. Pepponi, J. Goettlicher, M. Bañobre-López, J. Rivas, Intrinsic magnetism and hyperthermia in bioactive Fe-doped hydroxyapatite, Acta Biomaterialia 8 (2012) 843-851. 
[40] H.C. Wu, T.W. Wang, J.S. Sun, W.H. Wang, F.H. Lin, A novel biomagnetic nanoparticle based on hydroxyapatite, Nanotechnology, 18 (2007) 165601-165619.

[41] Z. Stojanovic, L. Veselinovic, S. Markovic, N. Ignjatovic, D. Uskokovic, Hydrothermal synthesis of nanosized pure and cobalt-exchanged hydroxyapatite, Mater. Manuf. Process., 24 (2009) 1096-1103.

[42] R.D. Shannon, Revised effective ionic radii and systematic studies of interatomic distances in halides and chalcogenides, Acta Crystallogr. A32 (1976) 751-767.

[43] J. Rodriguez-Carvajal, PROGRAM FullProf.2k - version 3.20; Laboratoire Léon Brillouin (CEA-CNRS): Saclay, France, 2005; FullProf.2k manual available on http://wwwllb.cea.fr/fullweb/fp2k/fp2k_divers.htm.

[44] L.B. Mc Cusker, R.B. Von Dreele, D.E. Cox, D. Louër, P. Scardi, Rietveld refinement guidelines. J Appl Cryst. 32 (1999) 36-50.

[45] R.J. Hill, Rietveld refinement round-robin. 1. Analysis of standard x-ray and neutron data for $\mathrm{PbSO}_{4}$. J Appl Cryst. 25 (1992) 589-610.

[46] N.V.Y. Scarlett, I.C. Madsen, L.M.D. Cranswick, T. Lwin, E. Groleau, G. Stephenson, M. Aylmore, N. Agron-Olshina, Outcomes of the International Union of Crystallography Commission on Powder Diffraction Round Robin on Quantitative Phase Analysis: Samples 2, 3, 4, synthetic bauxite, natural granodiorite and pharmaceuticals. J Appl Cryst. 35 (2002) 383400.

[47] N. Newville IFFEFIT : interactive EXAFS analysis and FEFF fitting. J Synchrotron Rad. 8 (2001) 322-324.

[48] B. Ravel ATOMS: crystallography for X-ray absorption spectroscopist. J Synchrotron Rad. 8 (2001) 314-316.

[49] J.J. Rehr, J. Mustre de Leon, S.I. Zabinsky, R.C. Albers, Theoretical X-ray absorption fine structure standards, J Am Chem Soc 113 (1991) 5135-5140. 
[50]M. Jiang, J. Terra, A.M. Rossi, M.A. Morales, E.M. Baggio Saitovitch, D.E. Ellis, $\mathrm{Fe}^{2+} / \mathrm{Fe}^{3+}$ substitution in hydroxyapatite: Theory and experiment, Phys. Rev. B 66 (2002) 224107.

[51] H.R. Low, N. Phonthammachai, A. Maignan, G.A. Stewart, T.J. Bastow, L.L. Ma, T.J. White, The Crystal Chemistry of Ferric Oxyhydroxyapatite, Inorg. Chem.,47 (2008) 1177411782.

[52] E. Cottrell, K.A. Kelley, A. Lanzirotti, R.A. Fischer, High-precision determination of iron oxidation state in silicate glasses using XANES, Chemical Geology, 268 (2009) 167179. 

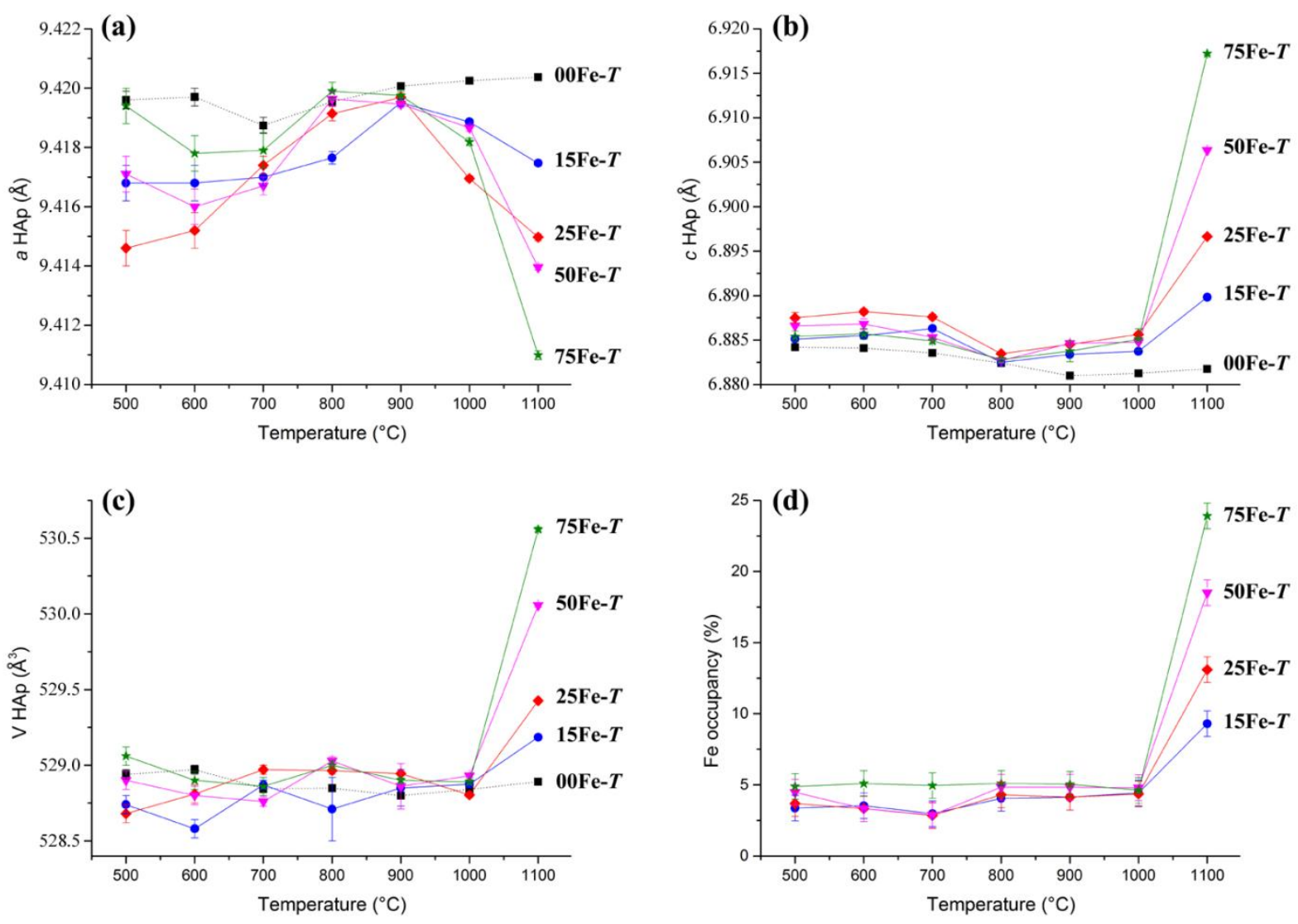

Figure 1. Thermal evolutions of the HAp lattice parameters: (a) lattice parameters $a$, (b) lattice parameter $c$, (c)the HAp unit cell volume, and (d)the Fe occupancyfactor attributed to the $2 b$ Wyckoff site $(0,0,0)$ (i.e. the adjacent 12 igeneral position $(x \sim 0.12, y=0, z=0)$ for samples heat treated at $1100^{\circ} \mathrm{C}$ ). The undoped series $00 \mathrm{Fe}-T$ (black squares, dotted lines), and the $\mathrm{Fe}-$ doped series $15 \mathrm{Fe}-T$ (blue circles, solid lines), $25 \mathrm{Fe}-T$ (red diamonds, solid lines),50Fe- $T$ (pink triangles, solid lines) and 75Fe- $T$ (green stars, solid lines) are represented. 

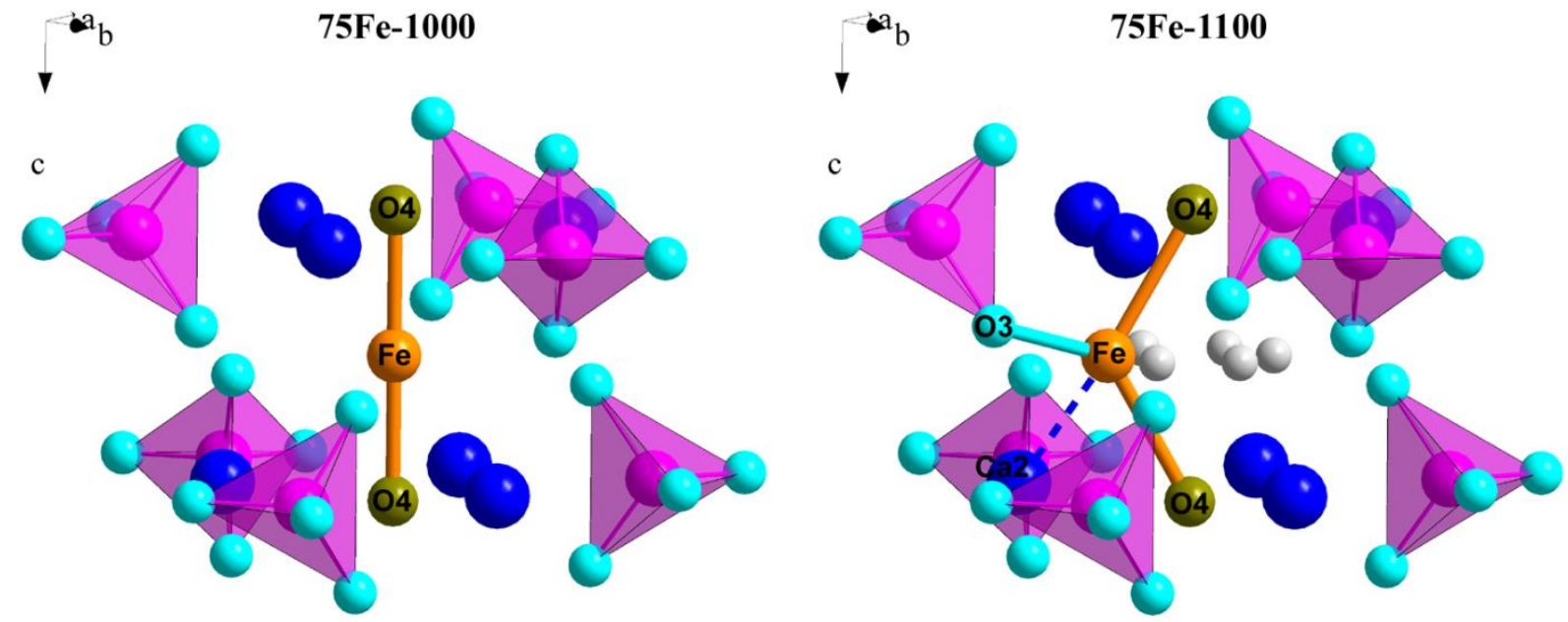

Figure 2.Structural details in the hexagonal channel of the HAp structure showing the passage from the two-fold coordination for $\mathrm{Fe}^{3+}$ observed up to $1000^{\circ} \mathrm{C}$ (left) to the three-fold coordination reached at $1100^{\circ} \mathrm{C}$ (right); i.e. shift from the $2 b$ Wycoff site located at $(0,0,0)$ to the $(0.12,0,0)$ position. Tetrahedra represent phosphate anions, large blue spheres represent calcium cation, green spheres represent hydroxyl site from HAp structure and orange spheres represent inserted iron cations. Small grey spheres illustrate the six equivalent $(0.12,0,0)$ positions for $\mathrm{Fe}^{3+}$ cation around the $2 b$ Wyckoff site. Dotted blue segment shows the short $\mathrm{Fe}^{3+}-\mathrm{Ca}^{2+}$ distance $(2.23 \AA$ ) according to crystallographic description. 

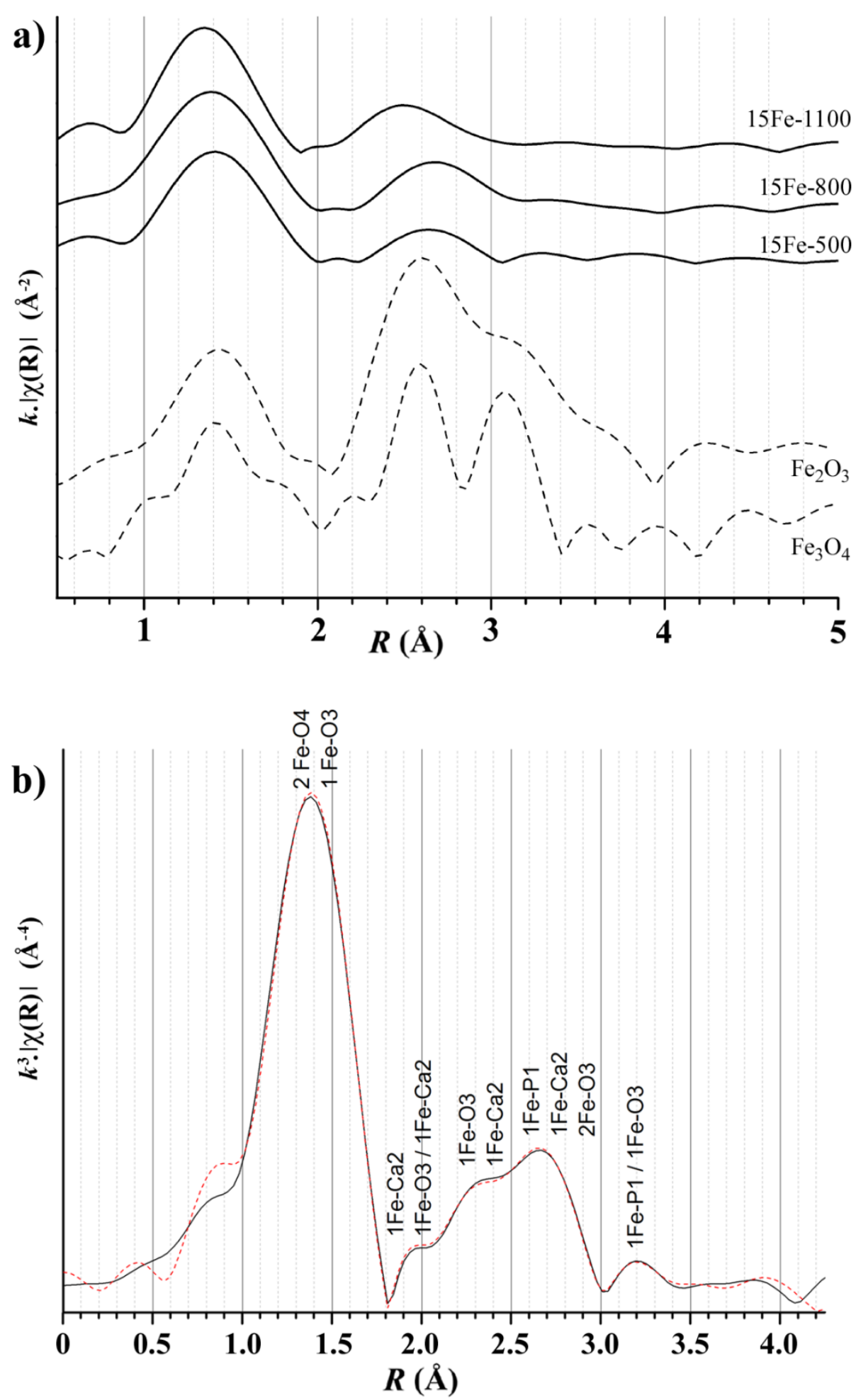

Figure 3.a) $k$-weighted amplitude of the Fourier transform uncorrected for phase shift for samples from the $15 \mathrm{Fe}-T$ series (solid lines) and the two reference compounds $\left(\mathrm{Fe}_{3} \mathrm{O}_{4}\right.$ and $\mathrm{Fe}_{2} \mathrm{O}_{3}$, dashed lines).b)fit in the $R$-space of the $k^{3}$-weighted amplitude of the Fourier transform uncorrected for phase shift for sample $15 \mathrm{Fe}-1100$. 


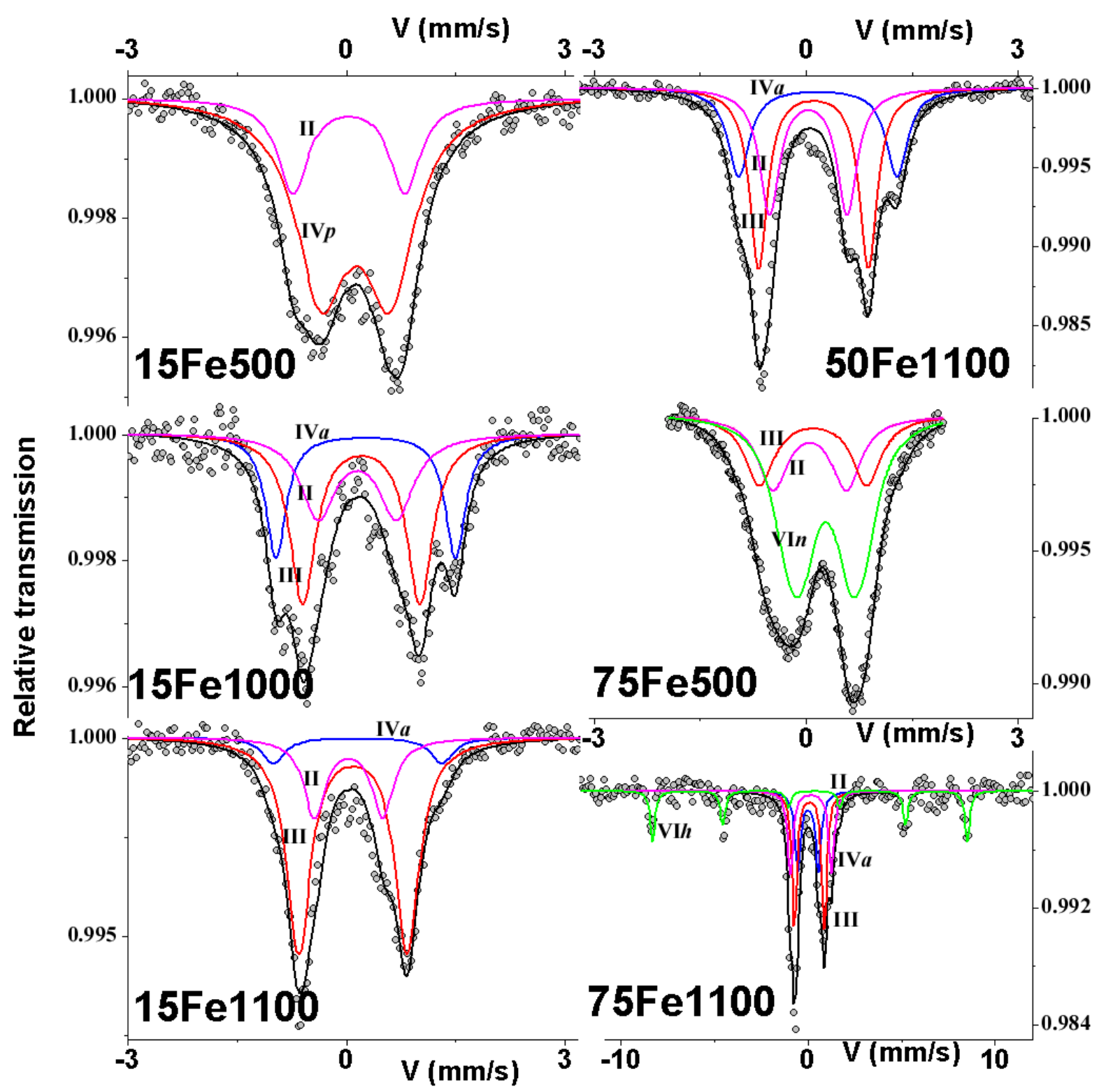

Figure 4. ${ }^{57} \mathrm{Fe}$ Mössbauer spectra obtained at $300 \mathrm{~K}$ and their decomposition after modelling, labels II, III, IV $p$, IV $a, \mathrm{VI} n$ and VI $h$ are reported in Table 4. 
Table 1. Results of the quantitative analyses (wt \%) extracted from Rietveld refinements for the undoped BCP series and the four Fe-doped BCP series. Standard deviations $(\sigma$ values from Rietveld treatments) are indicated in parentheses.

\begin{tabular}{|c|c|c|c|c|c|c|}
\hline \multirow[t]{2}{*}{ Samples } & \multicolumn{6}{|c|}{ Mineralogical composition (wt \%) } \\
\hline & HAp & $\beta$-ТCP & $\alpha-\mathrm{CDP}$ & $\mathrm{CaCO}_{3}$ & $\mathrm{CaO}$ & $\alpha-\mathrm{Fe}_{2} \mathrm{O}_{3}$ \\
\hline $00 \mathrm{Fe}-500$ & $91.2(9)$ & - & $4.4(3)$ & $3.70(15)$ & $0.79(9)$ & - \\
\hline $00 \mathrm{Fe}-600$ & $88.1(9)$ & $2.9(3)$ & $7.2(3)$ & $0.86(9)$ & $0.96(6)$ & - \\
\hline $00 \mathrm{Fe}-700$ & $87.1(9)$ & $7.9(3)$ & $3.9(3)$ & $0.46(3)$ & $0.64(3)$ & - \\
\hline $00 \mathrm{Fe}-800$ & $88.4(9)$ & $11.1(3)$ & - & - & $0.47(3)$ & - \\
\hline 00Fe-900 & $96.6(6)$ & $3.2(3)$ & - & - & $0.19(3)$ & - \\
\hline $00 \mathrm{Fe}-1000$ & $98.4(9)$ & $1.5(3)$ & - & - & $0.11(3)$ & - \\
\hline $00 \mathrm{Fe}-1100$ & $100(-)$ & - & - & - & - & - \\
\hline $15 \mathrm{Fe}-500$ & $90.5(4)$ & $2.9(1)$ & $4.0(1)$ & $2.64(6)$ & - & - \\
\hline $15 \mathrm{Fe}-600$ & 85.7 (4) & $7.3(1)$ & 7.0 (1) & - & - & - \\
\hline $15 \mathrm{Fe}-700$ & $79.2(3)$ & $17.8(1)$ & $3.0(1)$ & - & - & - \\
\hline $15 \mathrm{Fe}-800$ & 87.7 (3) & $12.3(1)$ & - & - & - & - \\
\hline $15 \mathrm{Fe}-900$ & $98.0(3)$ & $2.0(1)$ & - & - & - & - \\
\hline $15 \mathrm{Fe}-1000$ & $100(-)$ & - & - & - & - & - \\
\hline $15 \mathrm{Fe}-1100$ & $100(-)$ & - & - & - & - & - \\
\hline $25 \mathrm{Fe}-500$ & $88.8(5)$ & $2.8(1)$ & $4.6(1)$ & $3.7(1)$ & - & $0.19(5)$ \\
\hline $25 \mathrm{Fe}-600$ & $83.3(4)$ & $8.7(2)$ & 8.0 (1) & - & - & - \\
\hline $25 \mathrm{Fe}-700$ & $71.5(3)$ & $25.6(2)$ & $2.9(1)$ & - & - & - \\
\hline $25 \mathrm{Fe}-800$ & 76.4 (3) & $23.3(1)$ & - & - & - & $0.33(4)$ \\
\hline $25 \mathrm{Fe}-900$ & $89.3(3)$ & $10.1(1)$ & - & - & - & $0.58(3)$ \\
\hline $25 \mathrm{Fe}-1000$ & $92.0(3)$ & $7.15(9)$ & - & - & - & $0.85(3)$ \\
\hline $25 \mathrm{Fe}-1100$ & $88.2(3)$ & $11.8(2)$ & - & - & - & - \\
\hline $50 \mathrm{Fe}-500$ & $90.3(5)$ & $2.9(2)$ & $3.6(2)$ & $2.93(7)$ & - & $0.28(5)$ \\
\hline $50 \mathrm{Fe}-600$ & 85.0 (4) & $8.6(1)$ & 4.9 (1) & $1.13(7)$ & - & $0.32(5)$ \\
\hline $50 \mathrm{Fe}-700$ & $77.2(3)$ & $20.5(1)$ & $1.7(1)$ & - & - & $0.70(5)$ \\
\hline $50 \mathrm{Fe}-800$ & 84.8 (3) & 13.9 (1) & - & - & - & $1.27(4)$ \\
\hline $50 \mathrm{Fe}-900$ & 95.9 (3) & $2.24(8)$ & - & - & - & $1.84(4)$ \\
\hline $50 \mathrm{Fe}-1000$ & $97.8(4)$ & - & - & - & - & $2.22(4)$ \\
\hline $50 \mathrm{Fe}-1100$ & $100(-)$ & - & - & - & - & - \\
\hline $75 \mathrm{Fe}-500$ & $93.4(5)$ & $2.6(2)$ & $1.9(2)$ & $1.81(7)$ & - & $0.22(4)$ \\
\hline $75 \mathrm{Fe}-600$ & $90.6(5)$ & $6.3(2)$ & $1.9(2)$ & $0.82(8)$ & - & $0.42(5)$ \\
\hline $75 \mathrm{Fe}-700$ & $81.0(4)$ & $18.1(2)$ & - & - & - & $0.94(6)$ \\
\hline $75 \mathrm{Fe}-800$ & $85.4(3)$ & $12.5(1)$ & - & - & - & $2.08(4)$ \\
\hline $75 \mathrm{Fe}-900$ & 93.7 (4) & $2.8(1)$ & - & - & - & $3.51(4)$ \\
\hline $75 \mathrm{Fe}-1000$ & $95.5(4)$ & - & - & - & - & $4.50(5)$ \\
\hline $75 \mathrm{Fe}-1100$ & $99.3(5)$ & - & - & - & - & $0.71(4)$ \\
\hline
\end{tabular}


Table 2. Rietveld refinement results on Fe:HAp phases for $x \mathrm{Fe}-1100$ samples. Standard deviations ( $\sigma$ values from Rietveld treatments) are indicated in parentheses.

\begin{tabular}{|c|c|c|c|c|c|c|}
\hline Atom & Site & $x$ & $y$ & $z$ & $\mathrm{~B}_{\text {iso }}$ & Occupancy \\
\hline \multicolumn{7}{|c|}{$\begin{array}{l}P 6_{3} / m, \mathrm{Ca}_{10} \mathrm{Fe}_{0.18(1)}\left(\mathrm{PO}_{4}\right)_{6}(\mathrm{OH})_{1.46} \mathrm{O}_{0.54}, \mathrm{Z}=1 \\
a=9.41749(3) \AA, c=6.88983(3) \AA, \mathrm{V}=529.187(3) \AA^{3} \\
R_{\mathrm{Bragg}}=0.042, R_{\mathrm{p}}=0.034, R_{\mathrm{wp}}=0.045\end{array}$} \\
\hline $\begin{array}{l}\mathrm{Ca} 1 \\
\mathrm{Ca} 2 \\
\mathrm{P} 1 \\
\mathrm{O} 1 \\
\mathrm{O} 2 \\
\mathrm{O} 3 \\
\mathrm{O} 4 \\
\mathrm{Fe} 1 \\
\end{array}$ & $\begin{array}{l}4 f \\
6 h \\
6 h \\
6 h \\
6 h \\
12 i \\
4 e \\
12 i\end{array}$ & $\begin{array}{l}1 / 3 \\
0.2461(1) \\
0.3977(2) \\
0.3272(3) \\
0.5859(4) \\
0.3411(3) \\
0 \\
0.099(3) \\
\end{array}$ & \begin{tabular}{|l|}
$2 / 3$ \\
$0.9927(2)$ \\
$0.3676(2)$ \\
$0.4834(4)$ \\
$0.4655(4)$ \\
$0.2561(3)$ \\
0 \\
$0(-)$ \\
\end{tabular} & \begin{tabular}{|l|}
$0.0017(3)$ \\
$1 / 4$ \\
$1 / 4$ \\
$1 / 4$ \\
$1 / 4$ \\
$0.0698(3)$ \\
$0.206(1)$ \\
$0(-)$ \\
\end{tabular} & $\begin{array}{l}0.77(2) \\
=\mathrm{B}_{\text {iso }}(\mathrm{Ca} 1) \\
0.64(3) \\
0.69(4) \\
=\mathrm{B}_{\text {iso }}(\mathrm{O} 1) \\
=\mathrm{B}_{\text {iso }}(\mathrm{O} 1) \\
=\mathrm{B}_{\text {iso }}(\mathrm{O} 1) \\
=\mathrm{B}_{\text {iso }}(\mathrm{Ca} 1)\end{array}$ & $\begin{array}{l}1(-) \\
1(-) \\
1(-) \\
1(-) \\
1(-) \\
1(-) \\
1 / 2(-) \\
0.015(1) \\
\end{array}$ \\
\hline \multicolumn{7}{|c|}{$\begin{array}{l}\text { 25Fe-1100 } \\
\quad P 6_{3} / m, \mathrm{Ca}_{9.92(1)} \mathrm{Fe}_{0.26(1)}\left(\mathrm{PO}_{4}\right)_{6}(\mathrm{OH})_{1.38} \mathrm{O}_{0.62}, \mathrm{Z}=1 \\
a=9.41499(4) \AA, c=6.89666(3) \AA, \mathrm{A}=529.430(4) \AA^{3} \\
R_{\mathrm{Bragg}}=0.034, R_{\mathrm{p}}=0.030, R_{\mathrm{wp}}=0.040\end{array}$} \\
\hline $\begin{array}{l}\mathrm{Ca} 1 \\
\mathrm{Ca} 2 \\
\mathrm{P} 1 \\
\mathrm{O} 1 \\
\mathrm{O} 2 \\
\mathrm{O} 3 \\
\mathrm{O} 4 \\
\mathrm{Fe} 1 \\
\end{array}$ & $\begin{array}{l}4 f \\
6 h \\
6 h \\
6 h \\
6 h \\
12 i \\
4 e \\
12 i\end{array}$ & $\begin{array}{l}1 / 3 \\
0.2466(2) \\
0.3977(2) \\
0.3268(4) \\
0.5860(4) \\
0.3401(3) \\
0 \\
0.117(2) \\
\end{array}$ & \begin{tabular}{|l|}
$2 / 3$ \\
$0.9930(2)$ \\
$0.3679(2)$ \\
$0.4824(4)$ \\
$0.4648(4)$ \\
$0.2551(3)$ \\
0 \\
$0(-)$ \\
\end{tabular} & \begin{tabular}{|l|}
$0.0021(3)$ \\
$1 / 4$ \\
$1 / 4$ \\
$1 / 4$ \\
$1 / 4$ \\
$0.0697(3)$ \\
$0.206(1)$ \\
$0(-)$ \\
\end{tabular} & $\begin{array}{l}0.91(2) \\
=\mathrm{B}_{\text {iso }}(\mathrm{Ca} 1) \\
0.70(3) \\
1.01(4) \\
=\mathrm{B}_{\text {iso }}(\mathrm{O} 1) \\
=\mathrm{B}_{\text {iso }}(\mathrm{O} 1) \\
=\mathrm{B}_{\text {iso }}(\mathrm{O} 1) \\
=\mathrm{B}_{\text {iso }}(\mathrm{Ca} 1)\end{array}$ & $\begin{array}{l}1(-) \\
0.986(2) \\
1(-) \\
1(-) \\
1(-) \\
1(-) \\
1 / 2(-) \\
0.022(1) \\
\end{array}$ \\
\hline \multicolumn{7}{|c|}{$\begin{array}{l}\text { 50Fe-1100 } \\
P 6_{3} / m, \mathrm{Ca}_{9.84(1)} \mathrm{Fe}_{0.37(1)}\left(\mathrm{PO}_{4}\right)_{6}(\mathrm{OH})_{1.21} \mathrm{O}_{0.79}, \mathrm{Z}=1 \\
a=9.41395(4) \AA, c=6.90634(4) \AA, \mathrm{V}=530.057(4) \AA^{3} \\
R_{\text {Bragg }}=0.041, R_{\mathrm{p}}=0.030, R_{\mathrm{wp}}=0.040\end{array}$} \\
\hline $\begin{array}{l}\mathrm{Ca} 1 \\
\mathrm{Ca} 2 \\
\mathrm{P} 1 \\
\mathrm{O} 1 \\
\mathrm{O} 2 \\
\mathrm{O} 3 \\
\mathrm{O} 4 \\
\mathrm{Fe} 1\end{array}$ & $\begin{array}{l}4 f \\
6 h \\
6 h \\
6 h \\
6 h \\
12 i \\
4 e \\
12 i\end{array}$ & $\begin{array}{l}1 / 3 \\
0.2468(2) \\
0.3972(2) \\
0.3258(4) \\
0.5855(5) \\
0.3398(3) \\
0 \\
0.118(2) \\
\end{array}$ & \begin{tabular}{|l}
$2 / 3$ \\
$0.9928(2)$ \\
$0.3678(2)$ \\
$0.4822(4)$ \\
$0.4646(5)$ \\
$0.2541(3)$ \\
0 \\
$0(-)$
\end{tabular} & \begin{tabular}{|l|}
$0.0021(3)$ \\
$1 / 4$ \\
$1 / 4$ \\
$1 / 4$ \\
$1 / 4$ \\
$0.0703(2)$ \\
$0.209(1)$ \\
$0(-)$ \\
\end{tabular} & $\begin{array}{l}0.99(2) \\
=\mathrm{B}_{\text {iso }}(\mathrm{Ca} 1) \\
0.81(4) \\
0.92(5) \\
=\mathrm{B}_{\text {iso }}(\mathrm{O} 1) \\
=\mathrm{B}_{\text {iso }}(\mathrm{O} 1) \\
=\mathrm{B}_{\text {iso }}(\mathrm{O} 1) \\
=\mathrm{B}_{\text {iso }}(\mathrm{Ca} 1)\end{array}$ & $\begin{array}{l}1(-) \\
0.974(2) \\
1(-) \\
1(-) \\
1(-) \\
1(-) \\
1 / 2(-) \\
0.031(1)\end{array}$ \\
\hline \multicolumn{7}{|c|}{$\begin{array}{l}\text { 75Fe-1100 } \\
\quad P 6_{3} / m, \mathrm{Ca}_{9.77(1)} \mathrm{Fe}_{0.48(1)}\left(\mathrm{PO}_{4}\right)_{6}(\mathrm{OH})_{1.02} \mathrm{O}_{0.98}, \mathrm{Z}=1 \\
\quad a=9.41099(5) \AA, c=6.91722(4) \AA, \mathrm{V}=530.558(5) \AA^{3}\end{array}$} \\
\hline
\end{tabular}




\begin{tabular}{|c|l|l|l|l|l|l|}
\hline \multicolumn{2}{|l|}{$R_{\text {Bragg }}=0.039, R_{\mathrm{p}}=0.027, R_{\mathrm{wp}}=0.037$} \\
$\mathrm{Ca} 1$ & $4 f$ & $1 / 3$ & $2 / 3$ & $0.0023(3)$ & $1.13(2)$ & $1(-)$ \\
$\mathrm{Ca} 2$ & $6 h$ & $0.2471(2)$ & $0.9929(2)$ & $1 / 4$ & $=\mathrm{B}_{\text {iso }}(\mathrm{Ca} 1)$ & $0.962(2)$ \\
$\mathrm{P} 1$ & $6 h$ & $0.3966(2)$ & $0.3672(2)$ & $1 / 4$ & $1.00(5)$ & $1(-)$ \\
$\mathrm{O} 1$ & $6 h$ & $0.3255(4)$ & $0.4818(4)$ & $1 / 4$ & $1.02(5)$ & $1(-)$ \\
$\mathrm{O} 2$ & $6 h$ & $0.5846(5)$ & $0.4639(5)$ & $1 / 4$ & $=\mathrm{B}_{\text {iso }}(\mathrm{O} 1)$ & $1(-)$ \\
$\mathrm{O} 3$ & $12 i$ & $0.3389(3)$ & $0.2536(4)$ & $0.0700(3)$ & $=\mathrm{B}_{\text {iso }}(\mathrm{O} 1)$ & $1(-)$ \\
$\mathrm{O} 4$ & $4 e$ & 0 & 0 & $0.210(1)$ & $=\mathrm{B}_{\text {iso }}(\mathrm{O} 1)$ & $1 / 2(-)$ \\
$\mathrm{Fe} 1$ & $12 i$ & $0.121(2)$ & $0(-)$ & $0(-)$ & $=\mathrm{B}_{\text {iso }}(\mathrm{Ca} 1)$ & $0.040(1)$ \\
\hline
\end{tabular}


Table 3. Comparison of the Fe-local environment determined by XRPD Rietveld analysis and fit of the $k^{3}$-weighted EXAFS raw data for $15 \mathrm{Fe}-1100$.

\begin{tabular}{|c|c|c|c|c|c|}
\hline \multicolumn{2}{|c|}{ Fe shells } & \multirow{2}{*}{$\begin{array}{l}\text { XRPD Rietveld } \\
\mathrm{D}_{\mathrm{Fe}-X}(\AA)\end{array}$} & \multicolumn{2}{|r|}{ EXAFS fit } & \multirow{2}{*}{$\begin{array}{r}\text { Shift } \\
\Delta\left(\mathrm{d}_{\mathrm{Fe}-X}\right)(\AA)\end{array}$} \\
\hline $\mathrm{Fe}-X$ & $\mathrm{CN}$ & & $\mathrm{D}_{\mathrm{Fe}-X}(\AA)$ & $\sigma^{2}\left(\AA^{2}\right)$ & \\
\hline $\mathrm{Fe}-\mathrm{O} 4$ & 2 & $1.70(2)$ & $1.841(2)$ & $0.0035(3)$ & +0.14 \\
\hline $\mathrm{Fe}-\mathrm{O} 3^{(*)}$ & $\begin{array}{l}1 \\
1 \\
1 \\
1 \\
1 \\
1\end{array}$ & $\begin{array}{l}2.05(3) \\
2.39(1) \\
2.826(3) \\
3.32(2) \\
3.57(2) \\
3.64(2)\end{array}$ & $\begin{array}{l}1.941(7) \\
2.45(1) \\
2.90(2) \\
3.60(2) \\
3.6(2) \\
4.0(2)\end{array}$ & $\begin{array}{l}\sigma^{2}\left(\mathrm{PO}_{4}\right)=0.0071(6) \\
\sigma^{2}\left(\mathrm{PO}_{4}\right) \\
\sigma^{2}\left(\mathrm{PO}_{4}\right) \\
\sigma^{2}\left(\mathrm{PO}_{4}\right) \\
\sigma^{2}\left(\mathrm{PO}_{4}\right) \\
\sigma^{2}\left(\mathrm{PO}_{4}\right)\end{array}$ & $\begin{array}{l}-0.11 \\
+0.06 \\
+0.07 \\
+0.28 \\
+0.0 \\
+0.4\end{array}$ \\
\hline $\mathrm{Fe}-\mathrm{Ca} 2$ & $\begin{array}{l}1 \\
1 \\
1 \\
1 \\
1 \\
1\end{array}$ & $\begin{array}{l}2.23(2) \\
2.660(3) \\
2.696(2) \\
3.39(2) \\
3.42(2) \\
3.72(3)\end{array}$ & $\begin{array}{l}2.27(1) \\
2.466(6) \\
3.11(3) \\
3.50(7) \\
3.65(2) \\
4.2(4)\end{array}$ & $\begin{array}{l}\sigma^{2}(\mathrm{Ca})=0.0183(6) \\
\sigma^{2}(\mathrm{Ca}) \\
\sigma^{2}(\mathrm{Ca}) \\
\sigma^{2}(\mathrm{Ca}) \\
\sigma^{2}(\mathrm{Ca}) \\
\sigma^{2}(\mathrm{Ca})\end{array}$ & $\begin{array}{l}+0.04 \\
-0.20 \\
+0.41 \\
+0.11 \\
+0.23 \\
+0.5\end{array}$ \\
\hline Fe-P1 & 1 & $\begin{array}{l}3.18(2) \\
3.621(8) \\
3.729(5)\end{array}$ & $\begin{array}{l}3.17(1) \\
3.6(1) \\
3.98(2)\end{array}$ & $\begin{array}{l}=\sigma^{2}\left(\mathrm{PO}_{4}\right) \\
=\sigma^{2}\left(\mathrm{PO}_{4}\right) \\
=\sigma^{2}\left(\mathrm{PO}_{4}\right)\end{array}$ & $\begin{array}{l}-0.01 \\
+0.0 \\
+0.25\end{array}$ \\
\hline
\end{tabular}

${ }^{(*)}$ atoms belonging to the 6 neighbouring phosphate groups 
Table 4. Refinement results on the iron hyperfine parameters extracted from the Mössbauer spectra.

\begin{tabular}{|c|c|c|c|c|c|c|c|c|}
\hline Sample & $\begin{array}{c}\text { IS } \\
(\mathrm{mm} / \mathrm{s}) \\
\pm 0.02\end{array}$ & $\begin{array}{c}\Gamma \\
(\mathrm{mm} / \mathrm{s}) \\
\pm 0.02\end{array}$ & $\begin{array}{c}\mathrm{QS} / 2 \varepsilon \\
(\mathrm{mm} / \mathrm{s}) \\
\pm 0.03\end{array}$ & $\begin{array}{c}\mathrm{B}_{\mathrm{hf}} \\
(\mathrm{T}) \\
\pm .5\end{array}$ & $\begin{array}{c}\text { Populations } \\
\% \\
\pm 5\end{array}$ & $\begin{array}{c}\text { X-fold } \\
\text { Fe coord. }\end{array}$ & Assignment * & $\begin{array}{c}\text { Label in } \\
\text { Figure } 4\end{array}$ \\
\hline $15 \mathrm{Fe} 500$ & 0.15 & 0.50 & 1.51 & - & 23 & 2 & linear HAp & II \\
& 0.24 & 0.84 & 0.91 & - & 77 & 4 & tetra phys. & IVp \\
\hline $15 \mathrm{Fe} 1000$ & 0.17 & 0.33 & 1.01 & - & 29 & 2 & linear HAp & II \\
& 0.22 & 0.42 & 1.52 & - & 45 & 3 & triang. HAp & III \\
& 0.28 & 0.55 & 2.35 & - & 26 & 4 & tetra amorph. & IV $a$ \\
\hline $15 \mathrm{Fe} 1100$ & 0.15 & 0.36 & 0.90 & - & 23 & 2 & linear HAp & II \\
& 0.21 & 0.40 & 1.46 & - & 70 & 3 & triang. HAp & III \\
& 0.27 & 0.36 & 2.28 & - & 7 & 4 & tetra amorph. & IV $a$ \\
\hline $50 \mathrm{Fe} 1100$ & 0.15 & 0.34 & 1.07 & - & 33 & 2 & linear HAp & II \\
& 0.22 & 0.30 & 1.52 & - & 42 & 3 & triang. HAp & III \\
& 0.28 & 0.37 & 2.20 & - & 25 & 4 & tetra amorph. & IV $a$ \\
\hline $75 \mathrm{Fe} 500$ & 0.17 & 0.50 & 1.02 & - & 21 & 2 & linear HAp & II \\
& 0.22 & 0.50 & 1.50 & - & 19 & 3 & triang. HAp & III \\
& 0.40 & 0.62 & 0.87 & - & 60 & 6 & octa nano-H & VI $n$ \\
\hline $75 \mathrm{Fe} 1100$ & 0.16 & 0.37 & 1.00 & - & 22 & 2 & linear HAp & II \\
& 0.23 & 0.31 & 1.50 & - & 33 & 3 & triang. HAp & III \\
& 0.30 & 0.35 & 2.10 & - & 22 & 4 & tetra amorph. & IV $a$ \\
& 0.39 & 0.30 & -0.23 & 51.9 & 23 & 6 & octa hematite & VI $h$ \\
\hline
\end{tabular}

* - linear HAp corresponds the two-fold coordinated $\mathrm{Fe}^{3+}$ cation inserted in HAp.

- triang. HAp corresponds the three-fold coordinated $\mathrm{Fe}^{3+}$ cation inserted in HAp.

- tetra phys. corresponds the four-fold coordinated $\mathrm{Fe}^{3+}$ cation physisorbed at the HAp surface.

- tetra amorph. corresponds the four-fold coordinated $\mathrm{Fe}^{3+}$ cation located in the poorly crystalline HAp surface.

- octa nano-H corresponds the six-fold coordinated $\mathrm{Fe}^{3+}$ from nanosized $\mathrm{Fe}_{2} \mathrm{O}_{3}$.

- octa hematite corresponds the six-fold coordinated $\mathrm{Fe}^{3+}$ from $\mathrm{Fe}_{2} \mathrm{O}_{3}$. 
Supplementary Information 


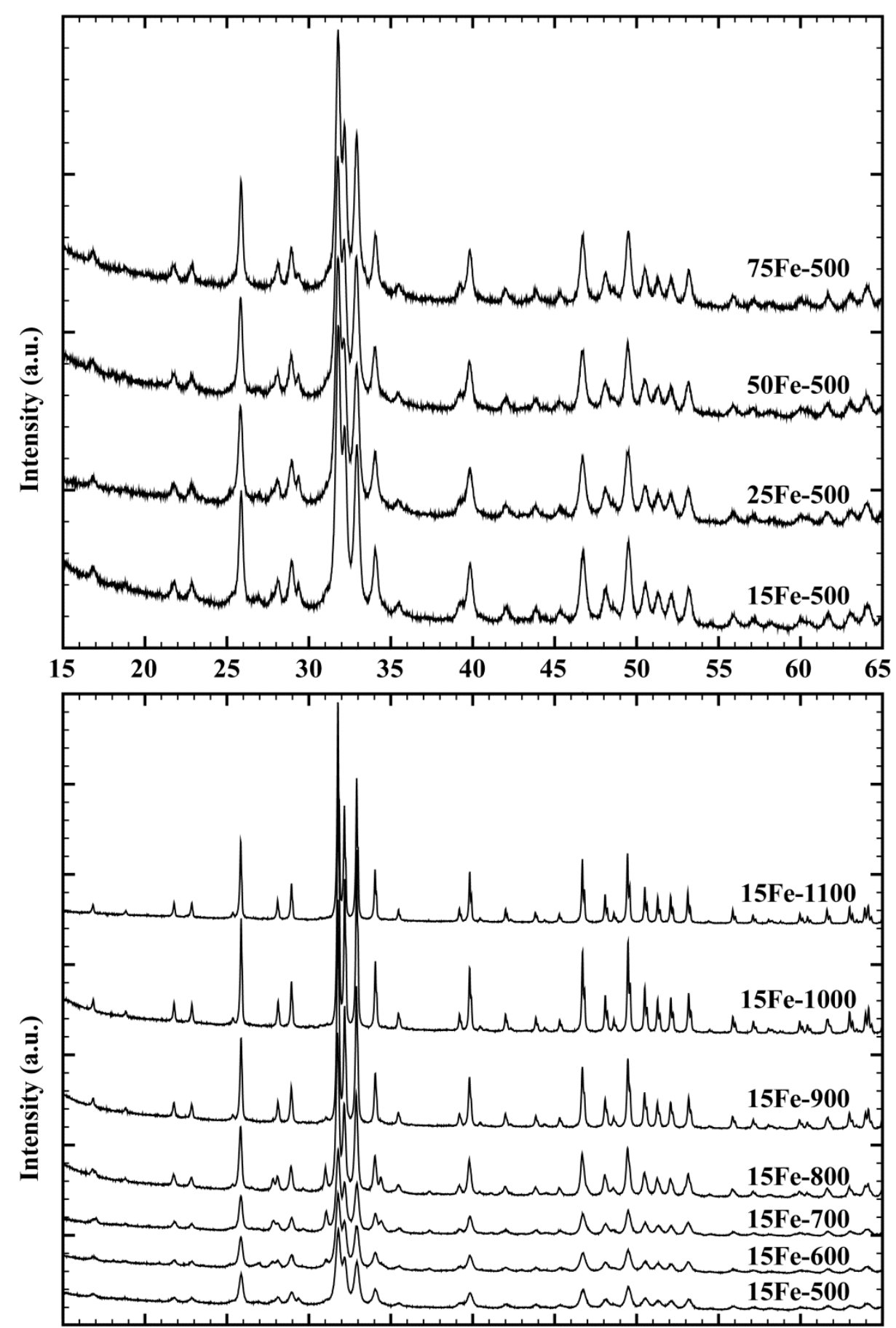


Figure SI1a. Exemples of XRPD raw data $\left(\lambda=1.54184 \AA\right.$, zoom showing the in the interval $15^{\circ}<2 \theta<80^{\circ}$ only) showing the iron content effect (top) and the temperature effect (bottom). 

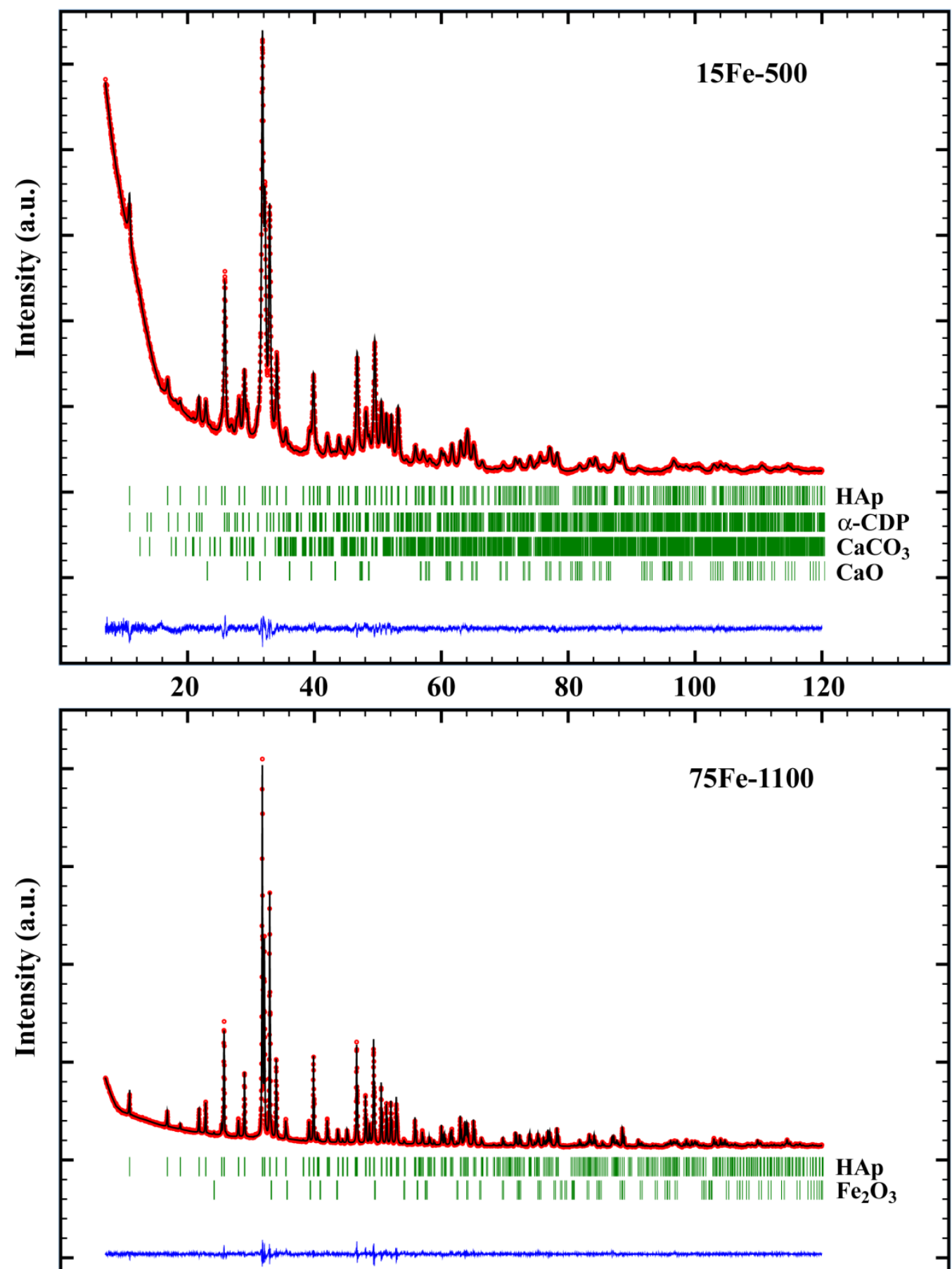
Figure SI1b.Exemples of Rietveld plots for $15 \mathrm{Fe} 500$ (top) and $75 \mathrm{Fe} 1100$ (bottom) $\operatorname{samples}(\lambda=1.54184 \AA$ ) showing the experimental points (red crosses), the calculated patterns (black lines), the difference curves (blue lines) and the Bragg peak positions with phase's indication (colored sticks).

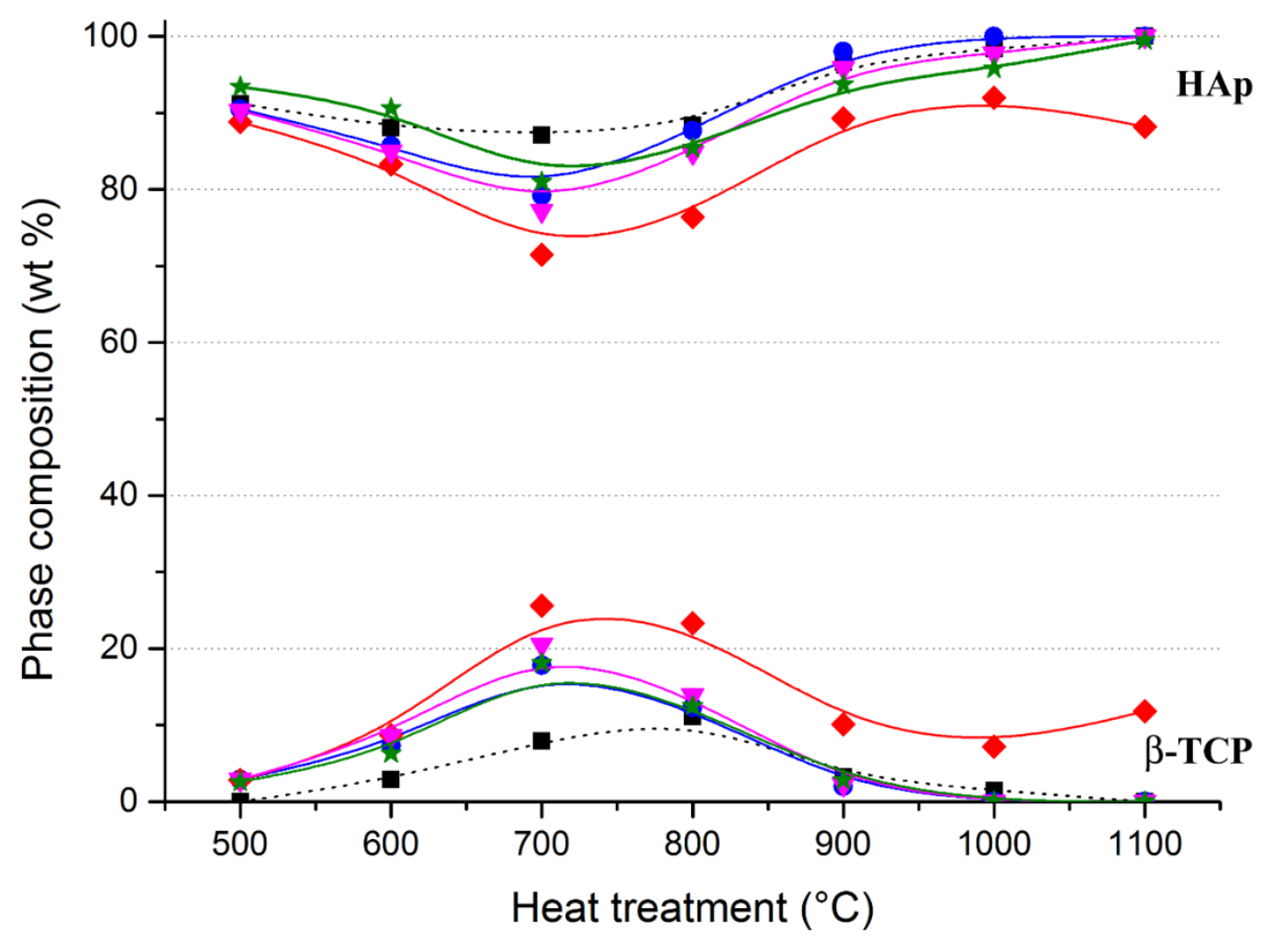


Figure SI2. Mineral composition of the two main phases (HAp and $\beta$-TCP) as function of the sintering temperature for the five series: undoped (black squares, dotted lines), 15Fe- $T$ (blue circles, solid lines), 25Fe- $T$ (red diamonds, solid lines), 50Fe- $T$ (pink triangles, solid lines) and $75 \mathrm{Fe}-T$ (green stars, solid lines). Solid lines are guides for the eyes only, and standard deviations, reported in Table 1, are too weak to be visualized. 

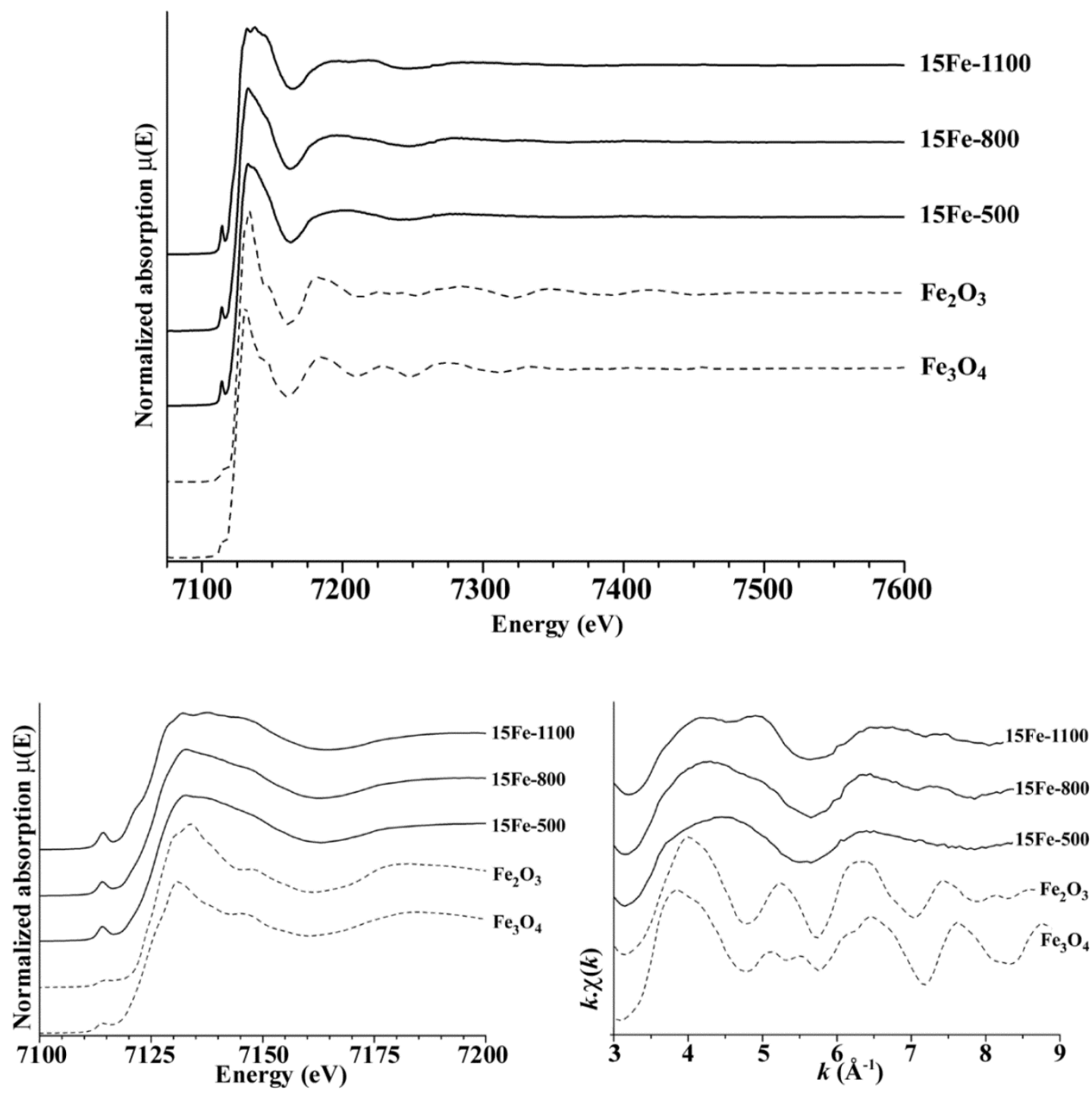
Figure SI3. Top: normalized EXAFS spectra at the Fe K edge $\left(\mathrm{E}_{0}=7109 \mathrm{eV}\right)$ for samples from the $15 \mathrm{Fe}-T$ series (solid lines) and reference compounds $\left(\mathrm{Fe}_{3} \mathrm{O}_{4}\right.$ and $\mathrm{Fe}_{2} \mathrm{O}_{3}$, dashed lines). Bottom left: XANES part of the spectra. Bottom right: the extracted $k$-weighted EXAFS modulations. 


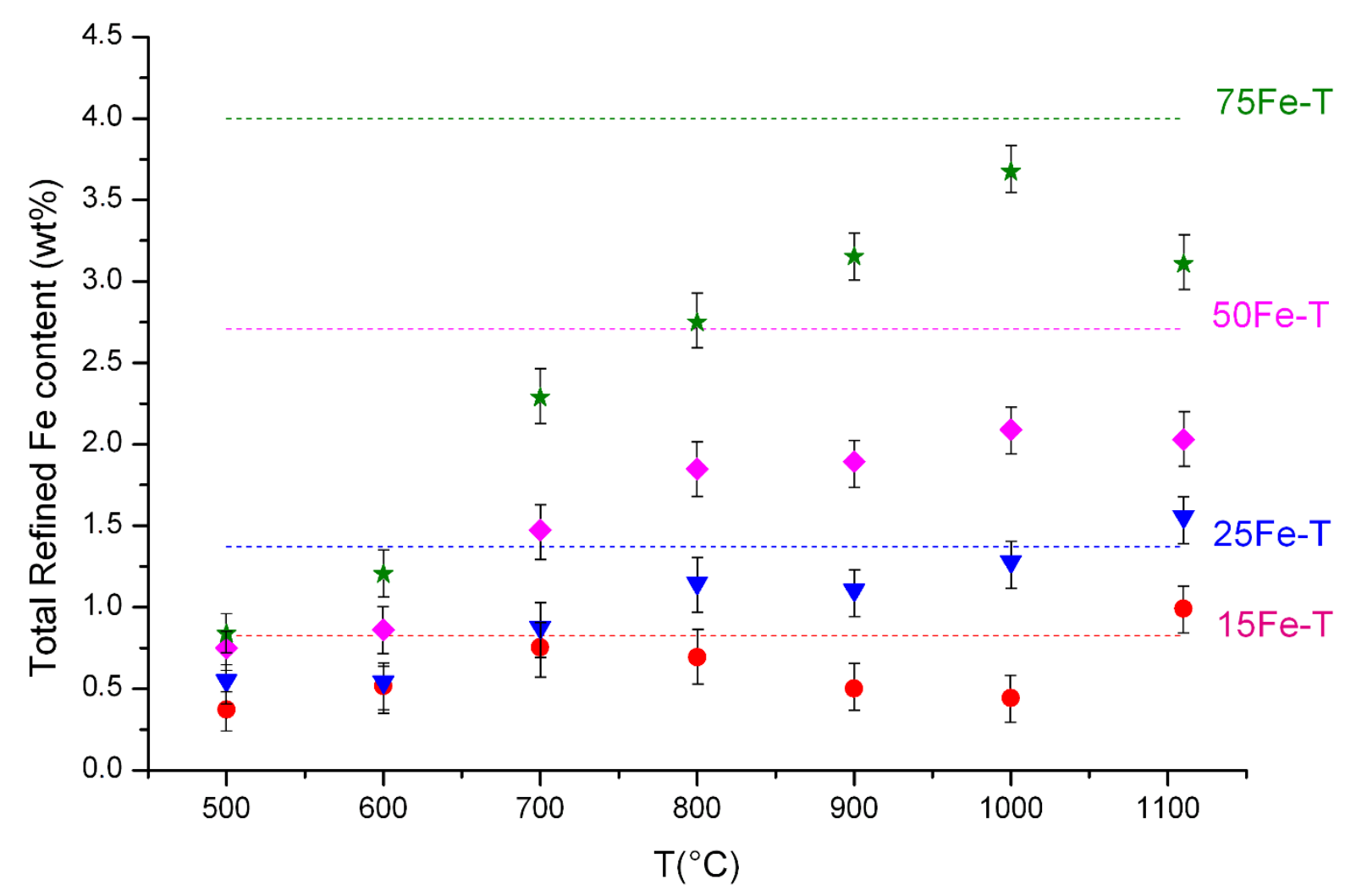

Figure SI4. Total refined $\mathrm{Fe}$ content in the samples considering iron insertion into both HAp and $\beta$-TCP phases and the $\mathrm{Fe}_{2} \mathrm{O}_{3}$ iron oxide for the four Fe-containing series (red circles, blue triangles, pink diamond and red stars for respectively the $15 \mathrm{Fe}-T, 25 \mathrm{Fe}-T, 50 \mathrm{Fe}-T$ and the $75 \mathrm{Fe}-T$ series. Dotted lines correspond to the targeted values. 
Table SI1. Structural parameters of the HAp phase obtained by Rietveld refinements. Standard deviations ( $\sigma$ values from Rietveld treatments) are indicated in parentheses.

\begin{tabular}{|l|l|l|l|l|l|}
\hline Samples & \multicolumn{5}{|c|}{ HAp structural parameters } \\
& $a(\AA)$ & $c(\AA)$ & $\mathrm{V}\left(\AA^{3}\right)$ & Fe Occ ${ }^{(*)}$ & Refined composition \\
\hline $00 \mathrm{Fe}-500$ & $9.4196(1)$ & $6.88419(10)$ & $528.94(1)$ & - & $\mathrm{Ca}_{10}\left(\mathrm{PO}_{4}\right)_{6}(\mathrm{OH})_{2}$ \\
\hline $00 \mathrm{Fe}-600$ & $9.4197(1)$ & $6.88410(9)$ & $528.97(1)$ & - & $\mathrm{Ca}_{10}\left(\mathrm{PO}_{4}\right)_{6}(\mathrm{OH})_{2}$ \\
\hline $00 \mathrm{Fe}-700$ & $9.41874(9)$ & $6.88356(8)$ & $528.846(9)$ & - & $\mathrm{Ca}_{10}\left(\mathrm{PO}_{4}\right)_{6}(\mathrm{OH})_{2}$ \\
\hline $00 \mathrm{Fe}-800$ & $9.41954(5)$ & $6.88241(4)$ & $528.848(5)$ & - & $\mathrm{Ca}_{10}\left(\mathrm{PO}_{4}\right)_{6}(\mathrm{OH})_{2}$ \\
\hline $00 \mathrm{Fe}-900$ & $9.42007(3)$ & $6.88100(3)$ & $528.799(3)$ & - & $\mathrm{Ca}_{10}\left(\mathrm{PO}_{4}\right)_{6}(\mathrm{OH})_{2}$ \\
\hline $00 \mathrm{Fe}-1000$ & $9.42025(2)$ & $6.88127(2)$ & $528.840(2)$ & - & $\mathrm{Ca}_{10}\left(\mathrm{PO}_{4}\right)_{6}(\mathrm{OH})_{2}$ \\
\hline $00 \mathrm{Fe}-1100$ & $9.42037(2)$ & $6.88176(2)$ & $528.891(2)$ & - & $\mathrm{Ca}_{10}\left(\mathrm{PO}_{4}\right)_{6}(\mathrm{OH})_{2}$ \\
\hline $15 \mathrm{Fe}-500$ & $9,4168(2)$ & $6,8851(1)$ & $528,74(2)$ & $3.3(3)$ & $\mathrm{Ca}_{10} \mathrm{Fe}_{0.07(1)}(\mathrm{PO})_{6}(\mathrm{OH})_{1.79} \mathrm{O}_{0.21}$ \\
\hline $15 \mathrm{Fe}-600$ & $9.4150(2)$ & $6.8855(1)$ & $528.58(2)$ & $3.5(3)$ & $\mathrm{Ca}_{10} \mathrm{Fe}_{0.07(1)}(\mathrm{PO})_{6}(\mathrm{OH})_{1.79} \mathrm{O}_{0.21}$ \\
\hline $15 \mathrm{Fe}-700$ & $9,4170(1)$ & $6.8863(1)$ & $528,87(1)$ & $3.0(3)$ & $\mathrm{Ca}_{10} \mathrm{Fe}_{0.06(1)}\left(\mathrm{PO}_{4}\right)_{6}(\mathrm{OH})_{1.82} \mathrm{O}_{0.18}$ \\
\hline $15 \mathrm{Fe}-800$ & $9,41765(7)$ & $6,88338(6)$ & $528,71(7)$ & $4.1(3)$ & $\mathrm{Ca}_{10} \mathrm{Fe}_{0.08(1)}\left(\mathrm{PO}_{4}\right)_{6}(\mathrm{OH})_{1.76} \mathrm{O}_{0.24}$ \\
\hline $15 \mathrm{Fe}-900$ & $9,41951(4)$ & $6,88249(4)$ & $528,85(4)$ & $4.0(3)$ & $\mathrm{Ca}_{10} \mathrm{Fe}_{0.08(1)}\left(\mathrm{PO}_{4}\right)_{6}(\mathrm{OH})_{1.76} \mathrm{O}_{0.24}$ \\
\hline $15 \mathrm{Fe}-1000$ & $9,41886(3)$ & $6,88474(3)$ & $528,874(4)$ & $4.4(3)$ & $\mathrm{Ca}_{10} \mathrm{Fe}_{0.09(1)}\left(\mathrm{PO}_{4}\right)_{6}(\mathrm{OH})_{1.73} \mathrm{O}_{0.27}$ \\
\hline $15 \mathrm{Fe}-1100$ & $9,41749(3)$ & $6,88983(3)$ & $529,187(3)$ & $9.3(3){ }^{(* *)}$ & $\mathrm{Ca}_{10} \mathrm{Fe}_{0.18(1)}(\mathrm{PO})_{6}(\mathrm{OH})_{1.46} \mathrm{O}_{0.54}$ \\
\hline
\end{tabular}




\begin{tabular}{|c|c|c|c|c|c|}
\hline $25 \mathrm{Fe}-500$ & $9.4146(2)$ & $6.8875(2)$ & $528.68(2)$ & $3.7(3)$ & $\mathrm{Ca}_{10} \mathrm{Fe}_{0.07(1)}\left(\mathrm{PO}_{4}\right)_{6}(\mathrm{OH})_{1.79} \mathrm{O}_{0.21}$ \\
\hline $25 \mathrm{Fe}-600$ & $9.4152(2)$ & $6.8882(1)$ & $528.81(2)$ & $3.3(3)$ & $\mathrm{Ca}_{10} \mathrm{Fe}_{0.07(1)}\left(\mathrm{PO}_{4}\right)_{6}(\mathrm{OH})_{1.79} \mathrm{O}_{0.21}$ \\
\hline $25 \mathrm{Fe}-700$ & $9,41704(1)$ & $6.8876(1)$ & $528,97(1)$ & $2.8(3)$ & $\mathrm{Ca}_{10} \mathrm{Fe}_{0.06(1)}\left(\mathrm{PO}_{4}\right)_{6}(\mathrm{OH})_{1.82} \mathrm{O}_{0.18}$ \\
\hline $25 \mathrm{Fe}-800$ & $9,41914(8)$ & $6.88451(7)$ & $528.964(8)$ & $4.1(3)$ & $\mathrm{Ca}_{10} \mathrm{Fe}_{0.08(1)}\left(\mathrm{PO}_{4}\right)_{6}(\mathrm{OH})_{1.76} \mathrm{O}_{0.24}$ \\
\hline $25 \mathrm{Fe}-900$ & $9.41969(5)$ & $6.88346(4)$ & $528.945(5)$ & $4.3(3)$ & $\mathrm{Ca}_{10} \mathrm{Fe}_{0.09(1)}\left(\mathrm{PO}_{4}\right)_{6}(\mathrm{OH})_{1.73} \mathrm{O}_{0.27}$ \\
\hline $25 \mathrm{Fe}-1000$ & $9.41703(3)$ & $6.88573(3)$ & $528.804(4)$ & $4.4(3)$ & $\mathrm{Ca}_{10} \mathrm{Fe}_{0.10(1)}\left(\mathrm{PO}_{4}\right)_{6}(\mathrm{OH})_{1.70} \mathrm{O}_{0.30}$ \\
\hline $25 \mathrm{Fe}-1100^{(* * *)}$ & $9.41499(4)$ & $6.89666(3)$ & $529.430(4)$ & $13.1(3)^{(* *)}$ & $\mathrm{Ca}_{9.92(1)} \mathrm{Fe}_{0.26(1)}\left(\mathrm{PO}_{4}\right)_{6}(\mathrm{OH})_{1.38} \mathrm{O}_{0.62}$ \\
\hline $50 \mathrm{Fe}-500$ & $9.4171(2)$ & $6.8866(2)$ & $528.9(2)$ & $4.5(3)$ & $\mathrm{Ca}_{10} \mathrm{Fe}_{0.09(1)}\left(\mathrm{PO}_{4}\right)_{6}(\mathrm{OH})_{1.73} \mathrm{O}_{0.27}$ \\
\hline $50 \mathrm{Fe}-600$ & $9.4160(2)$ & $6.8868(2)$ & $528.8(2)$ & $3.3(3)$ & $\mathrm{Ca}_{10} \mathrm{Fe}_{0.07(1)}\left(\mathrm{PO}_{4}\right)_{6}(\mathrm{OH})_{1.79} \mathrm{O}_{0.21}$ \\
\hline $50 \mathrm{Fe}-700$ & $9.4167(1)$ & $6.8853(1)$ & $528.8(1)$ & $2.9(3)$ & $\mathrm{Ca}_{10} \mathrm{Fe}_{0.06(1)}\left(\mathrm{PO}_{4}\right)_{6}(\mathrm{OH})_{1.82} \mathrm{O}_{0.18}$ \\
\hline $50 \mathrm{Fe}-800$ & $9.41963(8)$ & $6.88463(7)$ & $529.028(9)$ & $4.8(3)$ & $\mathrm{Ca}_{10} \mathrm{Fe}_{0.10(1)}\left(\mathrm{PO}_{4}\right)_{6}(\mathrm{OH})_{1.70} \mathrm{O}_{0.30}$ \\
\hline $50 \mathrm{Fe}-900$ & $9.41946(4)$ & $6.88268(4)$ & $528.86(5)$ & $4.8(3)$ & $\mathrm{Ca}_{10} \mathrm{Fe}_{0.10(1)}\left(\mathrm{PO}_{4}\right)_{6}(\mathrm{OH})_{1.70} \mathrm{O}_{0.30}$ \\
\hline $50 \mathrm{Fe}-1000$ & $9.41866(4)$ & $6.88476(3)$ & $528.930(4)$ & $4.8(3)$ & $\mathrm{Ca}_{10} \mathrm{Fe}_{0.10(1)}\left(\mathrm{PO}_{4}\right)_{6}(\mathrm{OH})_{1.70} \mathrm{O}_{0.30}$ \\
\hline $50 \mathrm{Fe}-1100^{(* * *)}$ & $9.41395(3)$ & $6.90634(3)$ & $530.057(4)$ & $18.5(3)^{(* *)}$ & $\mathrm{Ca}_{9.84(1)} \mathrm{Fe}_{0.37(1)}\left(\mathrm{PO}_{4}\right)_{6}(\mathrm{OH})_{1.21} \mathrm{O}_{0.79}$ \\
\hline $75 \mathrm{Fe}-500$ & $9.4194(2)$ & $6.8854(2)$ & $529.06(2)$ & $4.9(3)$ & $\mathrm{Ca}_{10} \mathrm{Fe}_{0.10(1)}\left(\mathrm{PO}_{4}\right)_{6}(\mathrm{OH})_{1.70} \mathrm{O}_{0.30}$ \\
\hline $75 \mathrm{Fe}-600$ & $9.4180(2)$ & $6.8857(2)$ & $528.90(2)$ & $5.1(3)$ & $\mathrm{Ca}_{10} \mathrm{Fe}_{0.10(1)}\left(\mathrm{PO}_{4}\right)_{6}(\mathrm{OH})_{1.70} \mathrm{O}_{0.30}$ \\
\hline $75 \mathrm{Fe}-700$ & $9.4179(2)$ & $6.8849(1)$ & $528.86(2)$ & $5.0(3)$ & $\mathrm{Ca}_{10} \mathrm{Fe}_{0.10(1)}\left(\mathrm{PO}_{4}\right)_{6}(\mathrm{OH})_{1.70} \mathrm{O}_{0.30}$ \\
\hline $75 \mathrm{Fe}-800$ & $9.4199(1)$ & $6.88376(8)$ & $529.00(1)$ & $5.0(3)$ & $\mathrm{Ca}_{10} \mathrm{Fe}_{0.10(1)}\left(\mathrm{PO}_{4}\right)_{6}(\mathrm{OH})_{1.70} \mathrm{O}_{0.30}$ \\
\hline $75 \mathrm{Fe}-900$ & $9.41975(5)$ & $6.8828(4)$ & $528.901(5)$ & $5.1(3)$ & $\mathrm{Ca}_{10} \mathrm{Fe}_{0.10(1)}\left(\mathrm{PO}_{4}\right)_{6}(\mathrm{OH})_{1.70} \mathrm{O}_{0.30}$ \\
\hline $75 \mathrm{Fe}-1000$ & $9.41819(4)$ & $6.88516(4)$ & $528.907(5)$ & $4.6(3)$ & $\mathrm{Ca}_{10} \mathrm{Fe}_{0.09(1)}\left(\mathrm{PO}_{4}\right)_{6}(\mathrm{OH})_{1.73} \mathrm{O}_{0.27}$ \\
\hline
\end{tabular}




\begin{tabular}{|l|l|l|l|l|l|}
\hline $75 \mathrm{Fe}-1100^{(* * *)}$ & $9.41099(5)$ & $6.91722(5)$ & $530.558(5)$ & $23.9(3)^{(* *)}$ & $\mathrm{Ca}_{9.77(1)} \mathrm{Fe}_{0.48(1)}\left(\mathrm{PO}_{4}\right)_{6}(\mathrm{OH})_{1.02} \mathrm{O}_{0.98}$ \\
\hline
\end{tabular}

* Fe occupancy in the interstitial $2 b$ Wyckoff site.

$* *$ occupancywith Fe atoms shifted from the $2 b$ Wyckoff site $(0,0,0)$ to the adjacent $12 i$ general position $(x \sim 0.12, y=0, z=0)$

$* * *$ calcium deficient hydroxyapatite were considered for Rietveld refinement performed on samples heat treated at $1100^{\circ} \mathrm{C}$. Calcium vacancies have been observed into the $\mathrm{Ca} 2$ crystallographic site for $25 \mathrm{Fe}-1100,50 \mathrm{Fe}-1100$ and $75 \mathrm{Fe}-1100$ samples. 
Table SI2. Structural parameters of the $\beta$-TCP phase obtained by Rietveld refinements. Standard deviations ( $\sigma$ values from Rietveld treatments) are indicated in parentheses.

\begin{tabular}{|l|l|l|l|l|l|l|}
\hline Samples & \multicolumn{7}{|c|}{$\beta$-TCP structural parameters } \\
& $a(\AA)$ & $c(\AA)$ & $V\left(\AA^{3}\right)$ & $\begin{array}{l}\text { Fe Occ } \\
\text { in Ca4 }\end{array}$ & $\begin{array}{l}\text { Fe Occ in } \\
\mathrm{Ca}{ }^{(*)}\end{array}$ & Refined composition \\
\hline $00 \mathrm{Fe}-800$ & $10.4260(2)$ & $37.3689(8)$ & $3517.85(9)$ & - & - & $\mathrm{Ca}_{3}\left(\mathrm{PO}_{4}\right)_{2}$ \\
\hline $15 \mathrm{Fe}-700$ & $10.4164(3)$ & $37.370(1)$ & $3511.5(2)$ & $50(-)$ & $0(-)$ & $\mathrm{Ca}_{2.86(-)} \mathrm{Fe}_{0.14(-)}\left(\mathrm{PO}_{4}\right)_{2}$ \\
\hline $25 \mathrm{Fe}-700$ & $10.4033(3)$ & $37.358(3)$ & $3501.5(2)$ & $50(-)$ & $0(-)$ & $\mathrm{Ca}_{2.86(-)} \mathrm{Fe}_{0.14(-)}\left(\mathrm{PO}_{4}\right)_{2}$ \\
\hline $50 \mathrm{Fe}-700$ & $10.3802(3)$ & $37.327(1)$ & $3483.1(2)$ & $50(-)$ & $20(10)$ & $\mathrm{Ca}_{2.80(3)} \mathrm{Fe}_{0.20(3)}\left(\mathrm{PO}_{4}\right)_{2}$ \\
\hline $75 \mathrm{Fe}-700$ & $10.3631(4)$ & $37.300(2)$ & $3469.10(2)$ & $50(-)$ & $80(10)$ & $\mathrm{Ca}_{2.63(3)} \mathrm{Fe}_{0.37(3)}\left(\mathrm{PO}_{4}\right)_{2}$ \\
\hline & & & & & & \\
\hline
\end{tabular}

* Fe occupancy (i.e. calcium substitution) in the Ca4 and Ca5 crystallographic site of the $\beta$-TCP structure. 
Table SI3. Rietveld refinement results on Fe:HAp phases for $x \mathrm{Fe}-1000$ samples. Standard deviations ( $\sigma$ values from Rietveld treatments) are indicated in parentheses

\begin{tabular}{|c|c|c|c|c|c|c|}
\hline Atom & Site & $x$ & $y$ & $z$ & $\mathrm{~B}_{\text {iso }}$ & Occ. \\
\hline \multicolumn{7}{|c|}{$\begin{array}{l}\text { 15Fe-1000 } \\
P 6_{3} / m, \mathrm{Ca}_{10} \mathrm{Fe}_{0.08(1)}\left(\mathrm{PO}_{4}\right)_{6}(\mathrm{OH})_{1.76} \mathrm{O}_{0.24}, \mathrm{Z}=1 \\
a=9.41886(3) \AA, c=6.88474(3) \AA, \mathrm{V}=528.874(3) \AA^{3} \\
R_{\mathrm{Bragg}}=0.049, R_{\mathrm{p}}=0.027, R_{\mathrm{wp}}=0.038\end{array}$} \\
\hline $\begin{array}{l}\mathrm{Ca} 1 \\
\mathrm{Ca} 2 \\
\mathrm{P} 1 \\
\mathrm{O} 1 \\
\mathrm{O} 2 \\
\mathrm{O} 3 \\
\mathrm{O} 4 \\
\mathrm{Fe} 1\end{array}$ & $\begin{array}{l}4 f \\
6 h \\
6 h \\
6 h \\
6 h \\
12 i \\
4 e \\
2 b \\
\end{array}$ & \begin{tabular}{|l|}
$1 / 3$ \\
$0.2464(1)$ \\
$0.3980(2)$ \\
$0.3246(3)$ \\
$0.5852(4)$ \\
$0.3395(3)$ \\
0 \\
0 \\
\end{tabular} & \begin{tabular}{|l|}
$2 / 3$ \\
$0.9935(2)$ \\
$0.3684(2)$ \\
$0.4828(4)$ \\
$0.4638(4)$ \\
$0.2547(3)$ \\
0 \\
0 \\
\end{tabular} & \begin{tabular}{|l|}
$0.0021(3)$ \\
$1 / 4$ \\
$1 / 4$ \\
$1 / 4$ \\
$1 / 4$ \\
$0.0702(3)$ \\
$0.208(1)$ \\
0 \\
\end{tabular} & $\begin{array}{l}0.72(2) \\
=B_{\text {iso }}(\mathrm{Ca} 1) \\
0.64(3) \\
0.61(4) \\
=\mathrm{B}_{\text {iso }}(\mathrm{O} 1) \\
=\mathrm{B}_{\text {iso }}(\mathrm{O} 1) \\
=\mathrm{B}_{\text {iso }}(\mathrm{O} 1) \\
=\mathrm{B}_{\text {iso }}(\mathrm{Ca} 1)\end{array}$ & \begin{tabular}{|l|}
$1(-)$ \\
$1(-)$ \\
$1(-)$ \\
$1(-)$ \\
$1(-)$ \\
$1(-)$ \\
$1 / 2(-)$ \\
$0.042(1)$ \\
\end{tabular} \\
\hline
\end{tabular}

\section{Fe-1000}

$P 6_{3} / m, \mathrm{Ca}_{10} \mathrm{Fe}_{0.10(1)}\left(\mathrm{PO}_{4}\right)_{6}(\mathrm{OH})_{1.70} \mathrm{O}_{0.30}, \mathrm{Z}=1$

$a=9.41703(3) \AA, c=6.88573(3) \AA, \mathrm{V}=528.820(4) \AA^{3}$

$R_{\text {Bragg }}=0.031, R_{\mathrm{p}}=0.027, R_{\mathrm{wp}}=0.038$

\begin{tabular}{l|l|l|l|l|l|l|}
$\mathrm{Ca} 1$ & $4 f$ & $1 / 3$ & $2 / 3$ & $0.0021(3)$ & $0.72(2)$ & $1(-)$ \\
$\mathrm{Ca} 2$ & $6 h$ & $0.2468(1)$ & $0.9937(2)$ & $1 / 4$ & $=\mathrm{B}_{\text {iso }}(\mathrm{Ca} 1)$ & $1(-)$ \\
$\mathrm{P} 1$ & $6 h$ & $0.3978(2)$ & $0.3683(2)$ & $1 / 4$ & $0.62(3)$ & $1(-)$ \\
$\mathrm{O} 1$ & $6 h$ & $0.3257(4)$ & $0.4828(4)$ & $1 / 4$ & $0.66(4)$ & $1(-)$ \\
$\mathrm{O} 2$ & $6 h$ & $0.5841(4)$ & $0.4628(4)$ & $1 / 4$ & $=\mathrm{B}_{\text {iso }}(\mathrm{O} 1)$ & $1(-)$ \\
$\mathrm{O} 3$ & $12 i$ & $0.3386(3)$ & $0.2545(3)$ & $0.0699(3)$ & $=\mathrm{B}_{\text {iso }}(\mathrm{O} 1)$ & $1(-)$ \\
$\mathrm{O} 4$ & $4 e$ & 0 & 0 & $0.207(1)$ & $=\mathrm{B}_{\text {iso }}(\mathrm{O} 1)$ & $1 / 2(-)$ \\
$\mathrm{Fe} 1$ & $2 b$ & 0 & 0 & 0 & $=\mathrm{B}_{\text {iso }}(\mathrm{Ca} 1)$ & $0.048(1)$ \\
\hline
\end{tabular}




\begin{tabular}{|c|c|c|c|c|c|c|}
\hline \multicolumn{7}{|c|}{$\begin{array}{l}\text { 50Fe-1000 } \\
P 6_{3} / m, \mathrm{Ca}_{10} \mathrm{Fe}_{0.10(1)}\left(\mathrm{PO}_{4}\right)_{6}(\mathrm{OH})_{1.70} \mathrm{O}_{0.30}, \mathrm{Z}=1 \\
a=9.41866(4) \AA, c=6.88476(3) \AA, \mathrm{V}=528.930(4) \AA^{3} \\
\quad R_{\text {Bragg }}=0.044, R_{\mathrm{p}}=0.025, R_{\mathrm{wp}}=0.034\end{array}$} \\
\hline $\mathrm{Ca} 1$ & $4 f$ & $\mid 1 / 3$ & $2 / 3$ & $\mid 0.0017(3)$ & $0.71(2)$ & $1(-)$ \\
\hline $\mathrm{Ca} 2$ & $6 h$ & $0.2466(2)$ & $0.9937(2)$ & $1 / 4$ & $=\mathrm{B}_{\mathrm{iso}}(\mathrm{Ca} 1)$ & $1(-)$ \\
\hline P1 & $6 h$ & $0.3981(2)$ & $0.3684(2)$ & $1 / 4$ & $0.64(4)$ & $1(-)$ \\
\hline $\mathrm{O} 1$ & $6 h$ & $0.3246(4)$ & $0.4830(4)$ & $1 / 4$ & $0.50(4)$ & $1(-)$ \\
\hline $\mathrm{O} 2$ & $6 h$ & $0.5847(4)$ & $0.4639(4)$ & $1 / 4$ & $=\mathrm{B}_{\text {iso }}(\mathrm{O} 1)$ & $1(-)$ \\
\hline $\mathrm{O} 3$ & $12 i$ & $0.3390(3)$ & $0.2543(3)$ & $0.0699(3)$ & $=\mathrm{B}_{\text {iso }}(\mathrm{O} 1)$ & $1(-)$ \\
\hline O4 & $4 e$ & 0 & 0 & $0.209(1)$ & $=\mathrm{B}_{\text {iso }}(\mathrm{O} 1)$ & $1 / 2(-)$ \\
\hline $\mathrm{Fe} 1$ & $2 b$ & 0 & 0 & 0 & $=\mathrm{B}_{\mathrm{iso}}(\mathrm{Ca} 1)$ & $0.048(1)$ \\
\hline \multicolumn{7}{|c|}{$\begin{array}{l}\text { 75Fe-1000 } \\
\quad P 6_{3} / m, \mathrm{Ca}_{10} \mathrm{Fe}_{0.10(1)}\left(\mathrm{PO}_{4}\right)_{6}(\mathrm{OH})_{1.70} \mathrm{O}_{0.30}, \mathrm{Z}=1 \\
a=9.41819(4) \AA, c=6.88516(4) \AA, \mathrm{V}=528.907(4) \AA^{3} \\
R_{\text {Bragg }}=0.043, R_{\mathrm{p}}=0.022, R_{\mathrm{wp}}=0.030\end{array}$} \\
\hline Ca1 & $4 f$ & $1 / 3$ & $2 / 3$ & $0.0019(3)$ & $0.71(2)$ & $1(-)$ \\
\hline $\mathrm{Ca} 2$ & $6 h$ & $0.2465(2)$ & $0.9935(2)$ & $1 / 4$ & $=\mathrm{B}_{\mathrm{iso}}(\mathrm{Ca} 1)$ & $1(-)$ \\
\hline P1 & $6 h$ & $0.3979(2)$ & $0.3682(2)$ & $1 / 4$ & $0.67(4)$ & $1(-)$ \\
\hline O1 & $6 h$ & $0.3253(4)$ & $0.4830(4)$ & $1 / 4$ & $0.54(4)$ & $1(-)$ \\
\hline $\mathrm{O} 2$ & $6 h$ & $0.5847(4)$ & $0.4639(5)$ & $1 / 4$ & $=\mathrm{B}_{\mathrm{iso}}(\mathrm{O} 1)$ & $1(-)$ \\
\hline $\mathrm{O} 3$ & $12 i$ & $0.3390(3)$ & $0.2544(3)$ & $0.0699(3)$ & $=\mathrm{B}_{\text {iso }}(\mathrm{O} 1)$ & $1(-)$ \\
\hline O4 & $4 e$ & 0 & 0 & $0.210(1)$ & $=\mathrm{B}_{\text {iso }}(\mathrm{O} 1)$ & $1 / 2(-)$ \\
\hline $\mathrm{Fe} 1$ & $2 b$ & 0 & 0 & 0 & $=\mathrm{B}_{\text {iso }}(\mathrm{Ca} 1)$ & $0.048(1)$ \\
\hline
\end{tabular}


Table SI4. Comparison of the iron local environment in $75 \mathrm{Fe}-1000$ (with Fe located into the $2 b$ site) and $75 \mathrm{Fe}-1100$ (with iron shifted at the $12 i$ $(0.12,0,0)$ coordinates $)$ samples.

\begin{tabular}{|c|c|c|c|c|c|c|c|}
\hline \multicolumn{4}{|c|}{$75 \mathrm{Fe}-1000$} & \multicolumn{4}{|c|}{$75 \mathrm{Fe}-1100$} \\
\hline \multicolumn{2}{|c|}{ Fe shells } & \multicolumn{2}{|c|}{ XRPD Rietveld } & \multicolumn{2}{|c|}{ Fe shells } & \multicolumn{2}{|c|}{ XRPD Rietveld } \\
\hline $\mathrm{Fe}-X$ & $\mathrm{CN}$ & $\mathrm{D}_{\mathrm{Fe}-X}(\AA)$ & $\mathrm{B}_{\text {iso }}(X)\left(\AA^{2}\right)$ & $\mathrm{Fe}-X$ & $\mathrm{CN}$ & $\mathrm{D}_{\mathrm{Fe}-X}(\AA)$ & $\mathrm{B}_{\text {iso }}(X)\left(\AA^{2}\right)$ \\
\hline $\mathrm{Fe}-\mathrm{O} 4$ & 2 & $1.446(9)$ & $0.54(4)$ & $\mathrm{Fe}-\mathrm{O} 4$ & 2 & $1.841(12)$ & $1.02(5)$ \\
\hline $\mathrm{Fe}-\mathrm{O} 3^{(*)}$ & 6 & $2.917(3)$ & $=\mathrm{B}_{\text {iso }}(\mathrm{O} 4)$ & $\mathrm{Fe}-\mathrm{O} 3^{(*)}$ & $\begin{array}{l}1 \\
1 \\
1 \\
1 \\
1 \\
1\end{array}$ & $\begin{array}{l}1.858(13) \\
2.291(6) \\
2.825(3) \\
3.402(9) \\
3.473(7) \\
3.723(4)\end{array}$ & $\begin{array}{l}=\mathrm{B}_{\text {iso }}(\mathrm{O} 4) \\
=\mathrm{B}_{\text {iso }}(\mathrm{O} 4) \\
=\mathrm{B}_{\text {iso }}(\mathrm{O} 4) \\
=\mathrm{B}_{\text {iso }}(\mathrm{O} 4) \\
=\mathrm{B}_{\text {iso }}(\mathrm{O} 4) \\
=\mathrm{B}_{\text {iso }}(\mathrm{O} 4)\end{array}$ \\
\hline $\mathrm{Fe}-\mathrm{Ca} 2$ & 6 & $2.915(2)$ & $0.71(2)$ & $\mathrm{Fe}-\mathrm{Ca} 2$ & $\begin{array}{l}1 \\
1 \\
1 \\
1 \\
1 \\
1\end{array}$ & $\begin{array}{l}2.229(8) \\
2.656(1) \\
2.698(1) \\
3.522(9) \\
3.555(9) \\
3.90(1)\end{array}$ & $\begin{array}{l}1.13(2) \\
=B_{\text {iso }}(\mathrm{Ca} 2) \\
=B_{\text {iso }}(\mathrm{Ca} 2) \\
=B_{\text {iso }}(\mathrm{Ca} 2) \\
=\mathrm{B}_{\text {iso }}(\mathrm{Ca} 2) \\
=\mathrm{B}_{\text {iso }}(\mathrm{Ca} 2)\end{array}$ \\
\hline
\end{tabular}

\footnotetext{
(*) atoms belonging to the 6 neighbouring phosphate group
} 
Comment SI1. Crystallographic description of iron environments into the HAp structure:

The local environment of the iron cations is strongly affected by the splitting observed between $1000^{\circ} \mathrm{C}$ and $1100^{\circ} \mathrm{C}$. $\mathrm{Up}^{\mathrm{p}}$ to $1000^{\circ} \mathrm{C}, \mathrm{Fe}^{3+}$ cations are located at the $2 b$ Wyckoff site, coordinates $(0,0,0)$, with a linear two-fold O-Fe-O coordination with two Fe-O4 distances around $1.7 \AA$. The following neighbors are six $\mathrm{O} 3$ atoms (from six different phosphate groups) at distances of about $2.9 \AA$, and six $\mathrm{Ca}^{2+}$ cations at a distance of about $2.9 \AA$. Due to the iron shift occurring at $1100^{\circ} \mathrm{C}, \mathrm{Fe}^{3+}$ cations are located at the $(0.12,0,0)$ position. Iron atoms are then three-fold coordinated in planar triangular coordination: two $\mathrm{O} 4$ positions (corresponding to the hydroxyl site in the HAp structure) at a distance of about $1.84 \AA$ and one $\mathrm{O} 3$ position (from one close phosphate anion) at a distance of about $1.86 \AA$. The next neighbor atom is a $\mathrm{Ca}^{2+}$ cation at only 2.23 $\AA$, according to the crystallographic description. Such a distance between the two $\mathrm{Fe}^{3+}$ and $\mathrm{Ca}^{2+}$ cation is clearly short (a distance of around $3.0 \AA$ would be more appropriate, as observed in calcium iron oxides [a]). In the present case, the fact that Fe $\mathrm{F}^{3+}$ cations are located at the interstitial site with limited occupancy could explain an underestimated inter-cationic distance related to statistical disorder.

[a] D.F. Becker, J.S. Kasper, The structure of calcium ferrite, Acta Crystallographica, 10 (1957) 332-337. 


\section{Comment SI2. Mössbauer spectroscopy}

${ }^{57} \mathrm{Fe}$ Mössbauer spectrometry was performed on several powdered samples at both $300 \mathrm{~K}$ and $77 \mathrm{~K}: 15 \mathrm{Fe}-500,15 \mathrm{Fe}-1000,15 \mathrm{Fe}-1100,50 \mathrm{Fe}-1100$, $75 \mathrm{Fe}-500$ and $75 \mathrm{Fe}-1100$. The aim was to provide local information about the different Fe species located in the present samples, and namely to characterize more precisely the low-coordinated interstitial $\mathrm{Fe}^{3+}$ cation from the iron-doped HAp phase. We can note their rather low statistics because of the weak Fe content, despite 3-4 days recording using a powerful radioactive source. Spectra recorded at $77 \mathrm{~K}$ are not discussed in the paper because they all show important disparities with those recorded at 300K. This suggests some atomic reordering or structural transition on cooling, but does not complement interpretations of the room temperature spectra.

Different fitting models, which consist of up to 5 or 6 quadrupolar doublets with lorentzian and narrow lines, can be proposed to describe the experimental spectra. But it remains a priori difficult to correlate the values of both the isomer shift (IS) and quadrupolar splitting (QS) versus the Fe content and the sintering temperature, contrarily to the mean isomer shift values which are independent of the fitting model. This local iron investigation highlights the complexity of our samples in terms of local iron structure. Unsurprisingly, $\mathrm{Fe}^{3+}$ cations are not located only in the main HAp phase, but also in minor $\beta$-TCP and also in $\alpha$-CDP and hematite impurities. On the other hand, it is necessary to consider a local environment distribution for the different iron-containing phases, and not simply a well-defined single environment ( $2 b$ splitting or not in HAp, five crystallographic $\mathrm{Ca}$ sites available for substitution in $\beta$-TCP, two crystallographic Ca sites available for substitution in $\alpha$-CDP, and even iron cations inserted into amorphous domain). 
The continuous transfer from the two-fold to the three-fold coordination from the split position of $\mathrm{Fe}^{3+}$ observed for the $15 \mathrm{Fe}$-series is less evident for samples containing greater amounts of iron. The $75 \mathrm{Fe}-500$ sample, sintered at $500^{\circ} \mathrm{C}$, seems already to contain a large amount of three-fold $\mathrm{Fe}^{3+}\left(48 \%\right.$ ), whereas the $75 \mathrm{Fe}-1100$ sample, sintered at $1100^{\circ} \mathrm{C}$, still contains $40 \%$ of two-fold $\mathrm{Fe}^{3+}$ (quite similarly to the $50 \mathrm{Fe}-1100$ sample). However, these last samples with a higher amount of incorporated iron contain supplementary iron including impurities, and Mössbauer spectra are polluted with complementary components. 